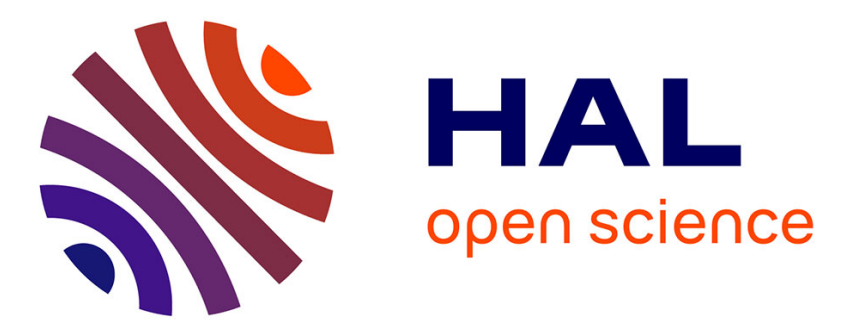

\title{
Synthesis, Electronic Properties and WOLED Devices of Planar Phosphorus-Containing Polycyclic Aromatic Hydrocarbons
}

François Riobé, Rózsa Szűcs, Pierre-Antoine Bouit, Denis Tondelier, Bernard Geffroy, Fátima Aparicio, Julia Buendía, Luis Sánchez, Régis Réau, László

Nyulászi, et al.

\section{To cite this version:}

François Riobé, Rózsa Szűcs, Pierre-Antoine Bouit, Denis Tondelier, Bernard Geffroy, et al.. Synthesis, Electronic Properties and WOLED Devices of Planar Phosphorus-Containing Polycyclic Aromatic Hydrocarbons. Chemistry - A European Journal, 2015, 21 (17), pp.6547-6556. 10.1002/chem.201500203 . hal-01130313

HAL Id: hal-01130313

https://hal-univ-rennes1.archives-ouvertes.fr/hal-01130313

Submitted on 23 May 2016

HAL is a multi-disciplinary open access archive for the deposit and dissemination of scientific research documents, whether they are published or not. The documents may come from teaching and research institutions in France or abroad, or from public or private research centers.
L'archive ouverte pluridisciplinaire HAL, est destinée au dépôt et à la diffusion de documents scientifiques de niveau recherche, publiés ou non, émanant des établissements d'enseignement et de recherche français ou étrangers, des laboratoires publics ou privés. 


\title{
Synthesis, electronic properties and WOLED devices of planar phosphorus-containing polycyclic aromatic hydrocarbons
}

\author{
François Riobé, ${ }^{[a]}$ Rózsa Szűcs, ${ }^{[a, b]}$ Pierre-Antoine Bouit, ${ }^{[a]}$ Denis Tondelier, ${ }^{[c]}$ Bernard Geffroy, ${ }^{[\mathrm{d}]}$ Fátima \\ Aparicio, ${ }^{[\mathrm{e}]}$ Julia Buendía, ${ }^{[\mathrm{e}]}$ Luis Sánchez, ${ }^{[\mathrm{e}]}$ Régis Réau, ${ }^{[\mathrm{a}]}$ László Nyulászi, ${ }^{*[\mathrm{~b}]}$ Muriel Hissler, ${ }^{[\mathrm{[a}]}$
}

Dedication ((optional))

\begin{abstract}
The article deals with the synthesis and the physical properties of polyaromatic hydrocarbons containing $P$-atom at the edge. In particular, the impact of the successive addition of aromatic rings on the electronic properties was investigated by experimental (UV-vis absorption, fluorescence, cyclic voltammetry) and theoretical studies (DFT). The physical properties recorded in solution and in solid state showed that the P-containing PAHs exhibit the expected properties to be used as emitter in WOLEDs.
\end{abstract}

\section{Introduction}

The rational design and synthesis of $\pi$-conjugated organic molecules have attracted growing attention in recent years owing to their potential use in the development of molecular opto-electronic and electronics. In 1D-linear heterole containing $\pi$-systems, the presence of different heteroatoms ( $B$, $\mathrm{Si}, \mathrm{N}, \mathrm{S}, \mathrm{P} \ldots$ ) allows the diversification of the electronic properties. ${ }^{[1]}$ For example, chemical modifications and coordination to transition metals of the $\sigma^{3}, \lambda^{3}-\mathrm{P}$ center allowed the development of new functional molecules (molecules $\mathbf{A}$ and B, Figure 1) which exhibit different electronic properties depending on the valence/coordination of the P-moiety. ${ }^{[2]}$ This straightforward and versatile property diversification led to the development of efficient materials for opto-electronic applications like organic light-emitting diodes (OLEDs). ${ }^{[3]}$

[a] Dr F. Riobé, R. Szücs, Dr P.-A. Bouit, Prof. R. Réau, Prof. M. Hissler,

Institut des Sciences Chimiques de Rennes, UMR6226 CNRSUniversité de Rennes 1, Campus de Beaulieu, 35042 Rennes Cedex, France

E-mail: mhissler@univ-rennes1.fr

[b] R. Szücs , Prof. L. Nyulászi

Department of Inorganic Chemistry, Budapest University of Technology and Economics, $\mathrm{H}-1521$ Budapest, Hungary E-mail: nyulaszi@mail.bme.hu

[c] Dr D. Tondelier

Laboratoire de Physique des Interfaces et Couches Minces, CNRS UMR 7647, Ecole Polytechnique, 91128 Palaiseau, France

[d] B. Geffroy

Laboratoire d'Innovation en Chimie des Surfaces et Nanosciences (LICSEN), UMR 3685 NIMBE, CEA Saclay 91191 Gif-sur-Yvette, Cedex, France

[e] F. Aparicio, J. Buendia, Prof. L. Sanchez

Departamento de Quimica Organica, Facultad de Ciencias

Quimicas, Universidad Complutense de Madrid, Ciudad Universitaria s/n 28040 Madrid, Spain

Supporting information for this article is given via a link at the end of the document

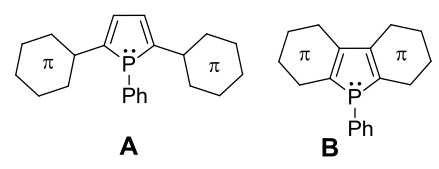

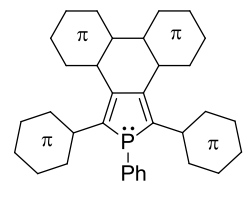

C

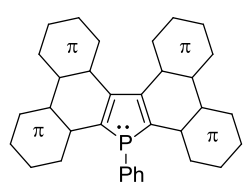

D

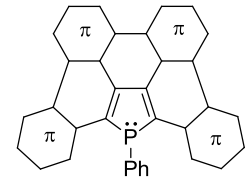

E
Figure 1. Example of phosphole oligomer (A), diarylphosphole (B), $\pi$ extended phospholes (C and $\mathbf{D})$ and generic structure of the targeted $\mathrm{P}$ containing $\mathrm{PAH}(\mathbf{E})$.

With the discovery of the outstanding properties of graphene, $2 \mathrm{D} \pi$-conjugated systems have also appeared quite recently as appealing materials for opto-electronic applications. ${ }^{[4]}$ In this context, benzocoronenes or nanographenes, which belong to the family of the polycyclic aromatic hydrocarbons (PAHs), were synthesized and used as active materials in solar cells ${ }^{[5]}$ or field effect transistors ${ }^{[6]}$. As shown for the linear $\pi$ conjugated oligomers, heterochemistry offers the possibility of property-tuning also in the case of these 2D-systems. PAHs containing $\mathrm{N},{ }^{[7]} \mathrm{S},{ }^{[8]} \mathrm{O},{ }^{[9]}$ and $\mathrm{B}^{[10]}$ were recently developed, showing a wide variety of electronic properties as well as chemical reactivity that cannot be reached with the classical all $s p^{2}-\mathrm{C}$ systems. Effectively, the introduction of electrondeficient or electron-rich heteroatoms in the polycyclic scaffold introduces either vacancies (holes) or low-lying nonbonding states (electrons) leading to $\pi$-systems with appealing optoelectronic properties that can be used as active materials in devices. ${ }^{[1]}$ It is noteworthy that only few $2 \mathrm{D}$-structures incorporating a phosphorus atom have been reported in the literature. For example, derivatives of type C (Figure 1) bearing bithiophene units at the 3,4 positions ${ }^{[12]}$ or phospholes fused with bithiophene or naphthyl groups in the 2-3 and 4-5 positions (molecule D, Figure 1) have been synthesized but the P-ring is not fully incorporated into the 2D framework. ${ }^{[2,13]}$ Hence, introducing a reactive $\mathrm{P}$-atom into a planar $\pi$ conjugated framework remains a synthetic challenge. In this field, we recently described the first planar P-containing PAHs $\mathbf{E}$ (Figure 1) by introducing the phosphole ring on the edge of the $\mathrm{PAH} .{ }^{[14]}$ The presence of the reactive $\sigma^{3}, \lambda^{3}-\mathrm{P}$ center, was then exploited as an easy way for molecular engineering of PAHs via P-chemical modifications. These chemical 
modifications on the P-atom afforded unprecedented derivatives displaying remarkably low HOMO-LUMO gaps.

Further tuning of the HOMO-LUMO gap can achieved by modifying the molecular size of these $\mathrm{P}$-containing $\mathrm{PAH}$. Effectively, the HOMO-LUMO gap is closely related to the number of resonant sextets in the PAH structure. ${ }^{[15]}$ In this paper, we detail the impact of successive addition of fused aromatic rings around the $\mathrm{P}$ on the physical properties by experimental (UV-vis absorption, fluorescence, cyclic voltammetry) and theoretical studies. The physical properties recorded in solution and in solid state showed that the $\mathrm{P}$ containing PAHs exhibit the expected properties to be inserted as active emitting material in White OLED devices showing the potential of these compounds for opto-electronic applications.

\section{Results and Discussion}

Synthesis. The phospholes 2 were prepared according to the "one-pot" Fagan-Nugent's route, an efficient method for phosphole synthesis. ${ }^{[16]}$ The intramolecular oxidative coupling of dialkynes 1a-b (Scheme 1) with 'zirconocene' followed by addition of dichlorophenylphosphine affords the $\sigma^{3}, \lambda^{3}$ phosphole ring which is readily transformed into the corresponding $\lambda^{4}, \sigma^{5}$-phosphole 2 (Scheme 1) in presence of $\mathrm{NaIO}_{4}$ or $\mathrm{S}_{8}$ in order to obtain air-stable and easy to handle derivatives. ${ }^{31} \mathrm{P}$ NMR chemical shifts are in the usual range of oxophospholes and thioxophopholes $(+39.2 \mathrm{ppm}$ and +58.7 , +58.0 ppm for $2 a^{\circ}, 2 a^{\mathbf{S}}$ and $2 \mathbf{b}^{\mathbf{S}}$ respectively) and all their ${ }^{1} \mathrm{H}$ and ${ }^{13} \mathrm{C}$ NMR spectroscopic data support the proposed structures. The structure of $2 a^{\mathbf{S}}$ was also confirmed by $\mathrm{X}$-ray diffraction study (see Figure 2).

The oxo- and thioxophospholes $2 \mathbf{a}^{\mathbf{O}}$ and $\mathbf{2} \mathbf{a}-\mathbf{b}^{\mathbf{S}}$ (Scheme 1) were then engaged in the photocyclization reaction $\left(h v, I_{2}\right)$. In the case of $2 \mathrm{a}^{0}$, a major product $3 \mathrm{a}^{0}\left({ }^{31} \mathrm{P} \mathrm{NMR},+39.6 \mathrm{ppm}\right)$ in which only one $\mathrm{C}-\mathrm{C}$ bond has been formed, was isolated by column chromatography in $10 \%$ yield. Increasing reaction time only led to higher amounts of the by-products and the use of propylene oxide (PPO) as acid scavenger in the media only allow observing traces of $\left.4 \mathrm{a}^{\circ} .{ }^{17}\right]$ In contrast, the thiooxophosphole $2 \mathrm{a}^{\mathbf{S}}$, which turned out to be less sensitive to the in situ generated $\mathrm{HI}$ (apparently, the proton affinity of sulphur is smaller than that of oxygen) has a different behaviour under irradiation. The photocyclization of $2 \mathrm{a}^{\mathbf{s}}$ in these conditions ( $h v, \mathrm{l}_{2}, \mathrm{PPO}$ ) led to a mixture of two compounds displaying ${ }^{31} \mathrm{P}$ NMR signals in the range of the thiooxophospholes. Column chromatography allowed to isolate both compounds and their structures were assigned to compound $4 \mathrm{a}^{\mathbf{S}}\left({ }^{31} \mathrm{P}\right.$ NMR, $+46.0 \mathrm{ppm}$; yield: $\left.20 \%\right)$ and $3 \mathrm{a}^{\mathbf{S}}\left({ }^{31} \mathrm{P}\right.$ NMR, +51.6 ppm yield: $50 \%$ ) (Scheme 1). Compared to $3 \mathrm{a}^{\mathbf{S}}$, which shows highly asymmetric ${ }^{1} \mathrm{H}$ and ${ }^{13} \mathrm{C}$ NMR spectra, the rather simple spectrum of $4 \mathbf{a}^{\mathrm{S}}$ is consistent with the highly symmetric P-containing $\mathrm{PAH}$. Both compounds were also characterized by $\mathrm{X}$-ray crystallography (vide infra). Using this approach, two dibenzophosphapentaphenes $\mathbf{4 a - b ^ { \mathbf { s } }}$ were synthesized and obtained as air stable orange compounds. ${ }^{[18]}$
It is worth noting that $\mathbf{4 b}^{\mathbf{S}}$, with the four hexyl chains, displays excellent solubility in most of the main organic solvents. This compound was also characterized by X-ray diffraction (vide infra). Notably, consecutive cyclization steps are accompanied by a gradual shift to higher field of the ${ }^{31} \mathrm{P}$ NMR signal from

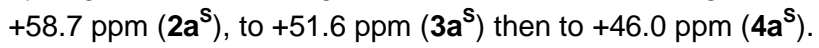

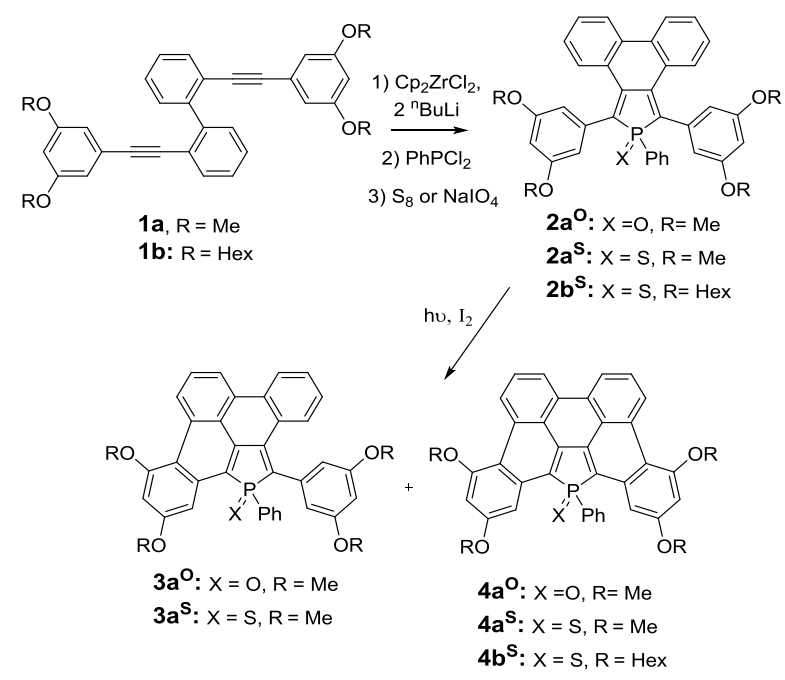

Scheme 1. Synthetic pathway for the preparation of phospholes 2-4.

Structural description. Compounds $2 a^{s}, 3 a^{s}$ and $4 a-b^{s}$ were characterized by $\mathrm{X}$-ray diffraction studies performed on single crystals (Figure 2). The bond length and valence angles for compound $2 \mathrm{a}^{\mathbf{S}}$ are classical and well compare with those observed for other $\pi$-conjugated phosphole derivatives. ${ }^{[3,12]}$ The lateral phenyl rings in the 2 and 5 positions lie perpendicular to the phosphole plane due to $\mathrm{H}-\mathrm{H}$ repulsions with the diphenyl moiety fused in 3,4 positions (Table 1, Figure 2 ). Interestingly, some distortion is observed between the phosphole ring and the diphenyl moiety (maximal deviation from the mean plane: $0.41 \AA$ ). This distortion was reproduced by geometry optimization performed by Density Functional Theory (DFT) calculations (vide infra). No intermolecular interactions were observed in the packing. In the case of $3 a^{s}$ and $\mathbf{4} \mathbf{a}-\mathbf{b}^{\mathbf{s}}$, the polycyclic $s p^{2}$-carbon atoms framework is planar (maximum deviation from the mean $\mathrm{C}-s p^{2}$ plane, 0.15 $\AA$ ) and the $\mathrm{P}$-atom lies in the $s p^{2}-\mathrm{C}$ plane (Figure 2). In both cases, the $\sigma^{4}, \lambda^{5}$-P-atom has a pyramidal shape with usual valence angles, and the $\mathrm{C}-\mathrm{C}$ and $\mathrm{C}-\mathrm{P}$ bond lengths in the phosphole ring are similar to those reported for phosphole oligomers (see Table 1 ). ${ }^{3}$ In case of $\mathbf{3} \mathbf{a}^{\mathbf{s}}$, the non-fused lateral phenyl ring lies again perpendicularly to the polycyclic plane due to $\mathrm{H}-\mathrm{H}$ repulsions (Figure 2) as observed in $2 \mathbf{a}^{\mathbf{s}}$. $^{19]}$ However, the major difference among $2 a^{\mathbf{s}}, 3 a^{\mathbf{s}}$ and $4 a^{-} \mathbf{b}^{\mathbf{s}}$ lies in the $\mathrm{C}-\mathrm{C}$ bond lengths in the polycyclic backbone. 


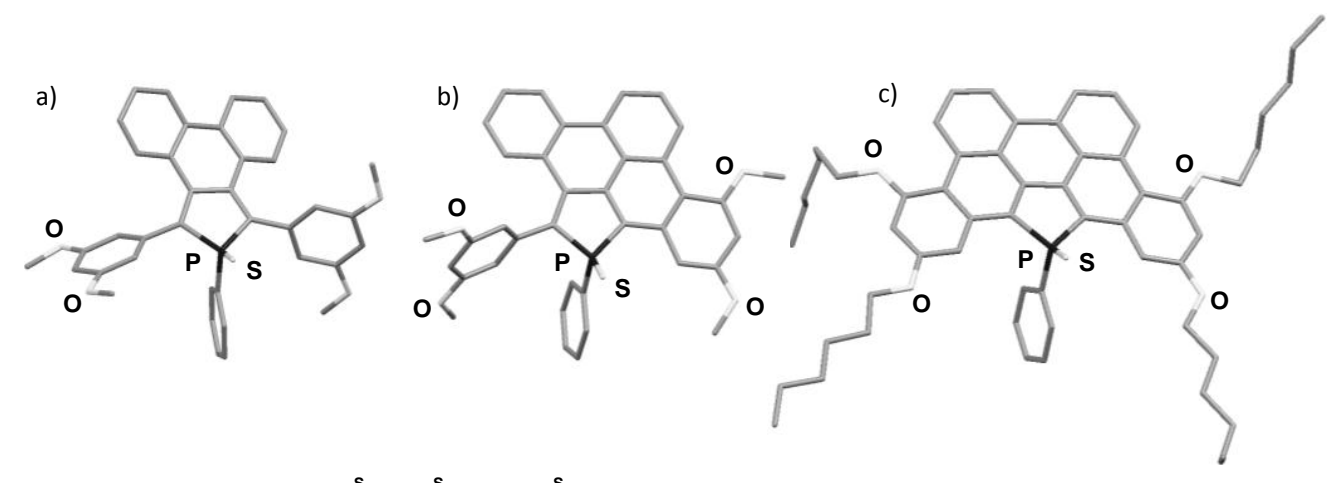

Figure 2 : X-ray crystallographic structures of a) $2 a^{s}$, b) $3 a^{s}$ and c) $4 b^{s}$. H atoms are omitted for clarity.

Of particular interest, $\mathrm{C}_{1}-\mathrm{C}_{2}, \mathrm{C}_{24}-\mathrm{C}_{23}, \mathrm{C}_{26}-\mathrm{C}_{27}$ and $\mathrm{C}_{25}-\mathrm{C}_{28}$ bond lengths in $\mathbf{4 a - \mathbf { b } ^ { \mathbf { s } }}$ are shortened $(\approx 1.42 \AA$, Table 1$)$ when 6 membered rings are formed, indicating an aromatic character for the newly formed ring. Furthermore, the $\mathrm{C}_{12}-\mathrm{C}_{13}$ bond length remains almost unchanged when the number of fused 6membered ring increases (Table 1). This observation indicates that the electronic behaviour of the phosphole's endocyclic ring differs from the other six membered rings. Effectively, the Bird indices calculated for compounds $2 a^{\mathrm{S}}, 3 \mathrm{a}^{\mathrm{S}}$ and $4 \mathrm{a}^{\mathrm{S}}$ (see table S5) indicate a gradual increase of the aromatic character not only for the phosphole ring but also for the endocyclic fused ring, showing that the phosphole ring has a significant impact on the electronic structure in the extended $\pi$-system. Presumably this increase is due to the planarization, which has a stronger effect on the geometry-based aromaticity indices than on the magneticbased NICS (vide infra).

Table 1. Selected bond lengths $[\AA]$ and dihedral angles $\left[^{\circ}\right]$ for compounds $2 a^{s}, 3 a^{s}$ and $4 a-b^{s}$.

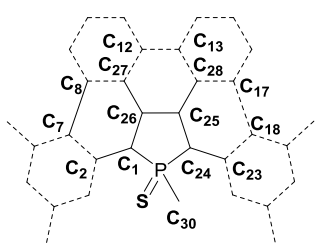

\begin{tabular}{|c|c|c|c|c|}
\hline & $2 \mathbf{a}^{s}$ & $3 \mathbf{a}^{\mathbf{s}}$ & $4 a^{s}$ & $4 b^{S}$ \\
\hline $\mathrm{P}-\mathrm{C}_{1}$ & 1.81 & 1.80 & 1.81 & 1.82 \\
\hline P-C 24 & 1.82 & 1.82 & 1.81 & 1.82 \\
\hline $\mathrm{C} 1-\mathrm{C} 26$ & 1.36 & 1.37 & 1.37 & 1.37 \\
\hline $\mathrm{C} 26-\mathrm{C} 25$ & 1.51 & 1.49 & 1.45 & 1.45 \\
\hline $\mathrm{C} 25-\mathrm{C} 24$ & 1.36 & 1.36 & 1.35 & 1.37 \\
\hline C1-C2 & 1.48 & 1.43 & 1.43 & 1.43 \\
\hline C26-C27 & 1.48 & 1.41 & 1.41 & 1.42 \\
\hline $\mathrm{C} 25-\mathrm{C} 28$ & 1.47 & 1.47 & 1.42 & 1.42 \\
\hline $\mathrm{C} 24-\mathrm{C} 23$ & 1.48 & 1.48 & 1.43 & 1.43 \\
\hline C12-C13 & 1.49 & 1.48 & 1.50 & 1.50 \\
\hline C7-C8 & - & 1.46 & 1.48 & 1.47 \\
\hline C17-C18 & - & - & 1.46 & 1.47 \\
\hline P- $\mathbf{C}_{1}-\mathrm{C}_{2}-\mathrm{C}_{7}$ & 67.4 & 6.5 & 2.6 & 2.0 \\
\hline $\mathrm{P}-\mathrm{C}_{24}-\mathrm{C}_{23}-\mathrm{C}_{18}$ & 47.3 & 102.5 & 8.0 & 3.6 \\
\hline
\end{tabular}

In the unit cell, $\mathbf{4 a} a^{S}$ and $\mathbf{4} b^{S}$ present discrete head-to-tail dimers with an intermolecular distance of ca. $3.5 \AA$ which is in the range of the $\pi$-stacking interactions (Figure $S 4$ ) but their packing structures are different. No long range intermolecular organization is observed for $\mathbf{4 a} \mathbf{a}^{\mathrm{S}}$ but intermolecular interactions can be observed for $\mathbf{4} b^{\mathbf{s}}$ due to a combination of intermolecular $\pi$ $\pi$ interactions $(\pi-\pi$ distances, $3.51 \AA)$ and $\mathrm{C}-\mathrm{H} \cdots \pi$ stacking interactions (C-H $\cdots \pi$ distances, $2.71 \AA$ ) (See Figure S4). No long range organisation has been observed for the compounds $2 \mathrm{a}^{\mathrm{s}}$ and $3 a^{\mathbf{s}}$.

To conclude, the structural analysis of $\mathbf{4 a - b ^ { \mathbf { s } }}$ and its precursors demonstrates that dibenzophosphapentaphenes possess both $\mathrm{PAH}$ and phosphole structural characteristics. The cyclization of the derivative is accompanied by the planarization of the aromatic system with the $\pi$-electrons being delocalized over the newly formed cycles.

Optical and electrochemical properties. The optical properties of dibenzophosphapentaphenes 2-4 were investigated by means of UV-Vis absorption and fluorescence measurements in dichloromethane. The absorption spectra of non-cyclized phospholes $\mathbf{2} \mathbf{a}-\mathbf{b}^{\mathbf{0}, \mathbf{s}}$ exhibit a broad $\pi-\pi^{*}$ transition with small extinction coefficient in the visible part of the spectrum (see Figure 3, Figure S5 and Table 2). ${ }^{[3]}$ This transition is gradually red-shifted and accompanied by a hyperchromic shift going from

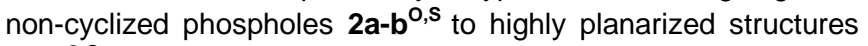
$4 a-b^{o, s}$. Furthermore, the rigidification of the structure leads to $a$ $\pi-\pi^{*}$ transition showing vibrational fine structures characteristic of polyaromatic molecules (Figure 3). ${ }^{[20]}$ Contrary to its two precursors $2 a^{\mathbf{S}}$ and $3 \mathrm{a}^{\mathrm{s}}$ that are not fluorescent in dichloromethane, $\mathbf{4} \mathbf{a}-\mathbf{b}^{\mathbf{s}}$ show intense and structured emission which is nearly the perfect mirror image of the absorption spectrum with respective maxima at $544 \mathrm{~nm}\left(\lambda_{\mathrm{abs}}{ }^{\max }=514 \mathrm{~nm}\right)$ (see Figure 3b, Table 2). This trend was also observed in case of the oxophosphole series $\left(2 a^{0}-3 a^{0}-4 a^{\circ}\right.$, see Figure S5). Low temperature emission spectra recorded in methylTHF at $77 \mathrm{~K}$ allowed to observe a better resolution of this vibronic progression (see Figure S6). The observed vibrational spacing $\left(1395 \mathrm{~cm}^{-1}\right.$ and $1351 \mathrm{~cm}^{-1}$ for $4 \mathrm{a}^{\mathrm{S}}$ ) corresponds to collective ring breathing vibrational mode with in-plane $\mathrm{CH}$ wagging vibrations, a highly intense characteristic feature in the Raman spectrum of the polyaromatic compounds. Indeed the Raman spectrum of compound $4 \mathrm{a}^{\mathrm{S}}$ shows two structured bands in well-defined spectral regions around $1600 \mathrm{~cm}^{-1}$ and $1300 \mathrm{~cm}^{-1}$ which can be 
correlated with the so-called $G$ and $D$ band regions characteristic of the Raman spectra of carbon materials containing $\mathrm{sp}^{2}$ carbon domain. ${ }^{[21]}$ The comparison between the experimental and the computed spectra obtained by DFT calculations for the lowest energy conformer (see below) are in good agreement with the experiment (Figure 4) and confirm that the most intense band in the $D$ band region corresponds with the breathing vibrational mode.

Table 2. Photophysical, electrochemical and thermal data.

\begin{tabular}{|c|c|c|c|c|c|c|c|}
\hline & $\begin{array}{l}\lambda_{\mathrm{atbs}}^{\text {[a] }} \\
{[\mathrm{nm}]}\end{array}$ & $\log \varepsilon^{[a]}$ & $\begin{array}{l}\lambda_{\mathrm{em}}{ }^{[a]} \\
{[\mathrm{nm}]}\end{array}$ & $\Phi_{\mathrm{F}}^{[\mathrm{b}]}$ & $\begin{array}{l}\mathrm{E}_{1}^{\mathrm{ox}}{ }_{1}^{[\mathrm{c}]} \\
{[\mathrm{V}]}\end{array}$ & $\begin{array}{l}\mathrm{E}_{1}^{\text {red }{ }_{1}[\mathrm{f}]} \\
{[\mathrm{V}]}\end{array}$ & $\begin{array}{l}\mathrm{Td}_{10}[\mathrm{e}] \\
\left({ }^{\circ} \mathrm{C}\right)\end{array}$ \\
\hline $2 a^{s}$ & 463 & 3.26 & - & - & +0.92 & $-1.58^{[\mathrm{d}]}$ & 362 \\
\hline $2 b^{S}$ & 465 & 3.20 & - & - & +0.92 & $-1.63^{[\mathrm{d}]}$ & \\
\hline $2 a^{o}$ & 448 & 3.22 & - & - & +1.01 & $-1.54^{[\mathrm{d}]}$ & \\
\hline $3 a^{s}$ & 468 & 3.85 & - & - & +0.79 & $-1.63^{[\mathrm{d}]}$ & 370 \\
\hline $3 a^{0}$ & 468 & 3.69 & - & - & +0.91 & $-1.62^{[\mathrm{d}]}$ & \\
\hline $4 a^{S}$ & 514 & 4.04 & 544 & 0.21 & +0.71 & $-1.70^{[\mathrm{d}]}$ & 318 \\
\hline $4 b^{S}$ & 518 & 4.20 & 545 & 0.23 & +0.67 & $-1.73^{[\mathrm{d}]}$ & 358 \\
\hline $4 a^{0}$ & 524 & 4.11 & 549 & 0.52 & +0.63 & $-1.71^{[\mathrm{d}]}$ & 388 \\
\hline
\end{tabular}

${ }^{[a]}$ In $\mathrm{CH}_{2} \mathrm{Cl}_{2}\left(10^{-5} \mathrm{M}\right) .{ }^{[b]}$ Measured relative to fluoresceine $(\mathrm{NaOH}, 0.1 \mathrm{M})$

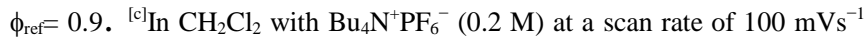
Potentials vs ferrocene/ferrocenium. ${ }^{[\mathrm{d}]}$ reversible process. ${ }^{[\mathrm{e}]}$ Decomposition temperature at $10 \%$ weight loss, measured by thermogravimetric analysis (TGA) under nitrogen.
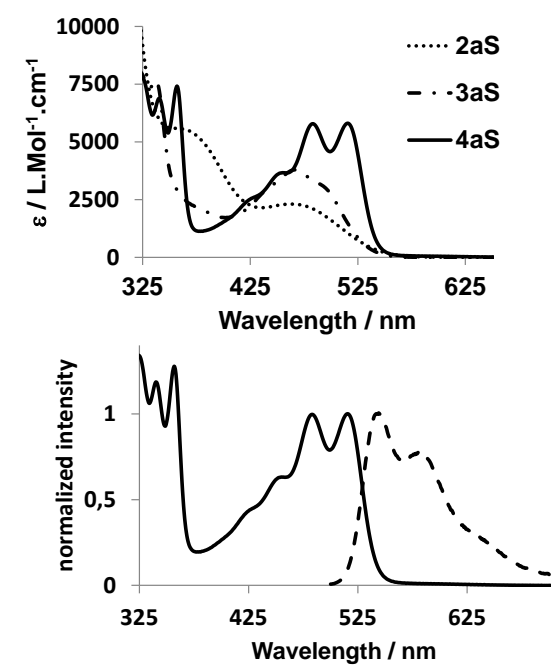

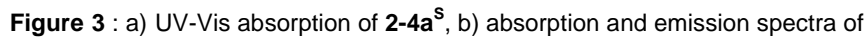
$4 \mathbf{a}^{\mathrm{S}}$ recorded at room temperature. $\left(\mathrm{CH}_{2} \mathrm{Cl}_{2}, \mathrm{C}=5.10^{-5} \mathrm{M}\right)$

Cyclic voltammetry $\left(\mathrm{CH}_{2} \mathrm{Cl}_{2}, 0.2 \mathrm{M} \mathrm{Bu}_{4} \mathrm{NPF}_{6}, \mathrm{v}=200 \mathrm{mV} . \mathrm{s}^{-1}\right)$ was used to investigate the redox properties of compounds 2-4. The non-cyclized phosphole $2 \mathrm{a}^{\mathrm{s}}$ undergoes irreversible oxidation $\left(\mathrm{E}^{\mathrm{ox}}{ }_{1}=+0.92 \mathrm{~V}\right.$ vs $\left.\mathrm{Fc} / \mathrm{Fc}^{+}\right)$and reversible reduction processes $\left(\mathrm{E}^{\text {red }}{ }_{1}=-1.58 \mathrm{~V}\right.$ vs $\left.\mathrm{Fc} / \mathrm{Fc}^{+}\right)$, confirming the high electron affinity of this family of derivatives. ${ }^{[12]}$ The consecutive formation of the two intramolecular bonds $\left(\mathbf{2} \mathbf{a}^{\mathbf{S}} \rightarrow \mathbf{3} \mathbf{a}^{\mathbf{S}} \rightarrow \mathbf{4} \mathbf{a}^{\mathbf{s}}\right)$ induces a gradual decrease of both oxidation and reduction potentials (Table 2). This effect is even more pronounced on the oxidation potential, which finally leads to a decrease of the gap, as observed by UVVis absorption and is also supported by DFT calculations (vide infra).

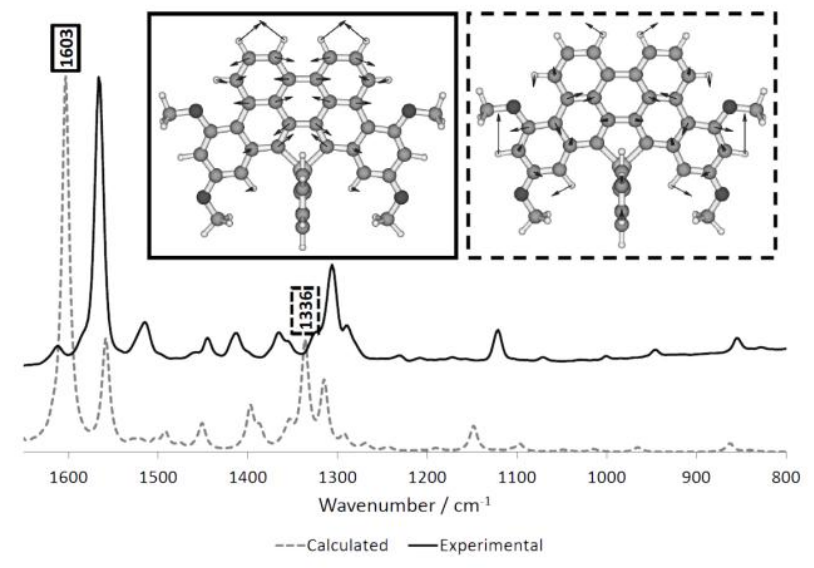

Figure 4 : Experimental (up, continuous line) and simulated (down, dotted line) Raman spectra of compound $4 \mathrm{a}^{\mathrm{s}}$. Characteristic vibration bands of $\mathrm{G}$ (black rectangle) and $D$ (dotted rectangle) band regions of the Raman spectra of carbon materials containing $\mathrm{sp}^{2}$ carbon domain.

Theoretical calculations. To understand the effect of the extension of the $\pi$-system on the physical properties, $2 a^{\mathrm{s}, 0}, 3 a^{\mathrm{s}, \mathrm{O}}$ and $4 a^{\mathrm{S}, \mathrm{O}}$ were investigated computationally. In the $2 \mathrm{a}^{\circ}, 3 \mathrm{a}^{\mathrm{O}}, \mathbf{4 a ^ { \circ }}$ series the raising of the HOMO level is accompanied by a small destabilization of the LUMO (see Figure 5) resulting in a reduction of the HOMO-LUMO gap, in accordance with the changes observed for redox and optical properties of these compounds. In case of the sulfur analogue, the change in the HOMO-LUMO energy difference is especially small between $2 a^{\mathbf{s}}$ and $3 \mathbf{a}^{\mathbf{s}}$, which is in contrast with the expectations that the extension of the $\pi$-system lowers the HOMO-LUMO gap. Inspection of the HOMOs, however reveals that in case of $2 \mathrm{a}^{\mathrm{s}}$ the lone pair of the sulfur (situated at phosphorus) can interact with the $\pi$-system (that is in closed energy) in the HOMO, resulting in an energy increase. This contribution is less significant in case of $3 a^{\mathrm{s}}$. For $4 a^{\mathrm{s}}$, where the $\pi$-system is extended over the carbon-carbon framework (resulting in an energy, which is higher than that of the sulfur lone pair), the mixing with the sulfur lone pair is insignificant and therefore their energy splitting is much smaller than it was in the previous case. Most notable is, however the fact that the frontier molecular orbitals (FMO-s) are directly derivable from the phosphole FMO-s, noticeably showing the conjugation with the extended $\pi$-system. This behaviour was noted before in case of $4 a^{s}$ (and its derivatives) ${ }^{[14]}$ but the fact that smaller $\pi$-systems and even the non-symmetric $3 a^{s}$ retains the phosphole-type HOMO and LUMO is noteworthy. It is of apparent interest whether with further increase of the $\pi$-system this characteristic feature of the FMO-s prevails. 


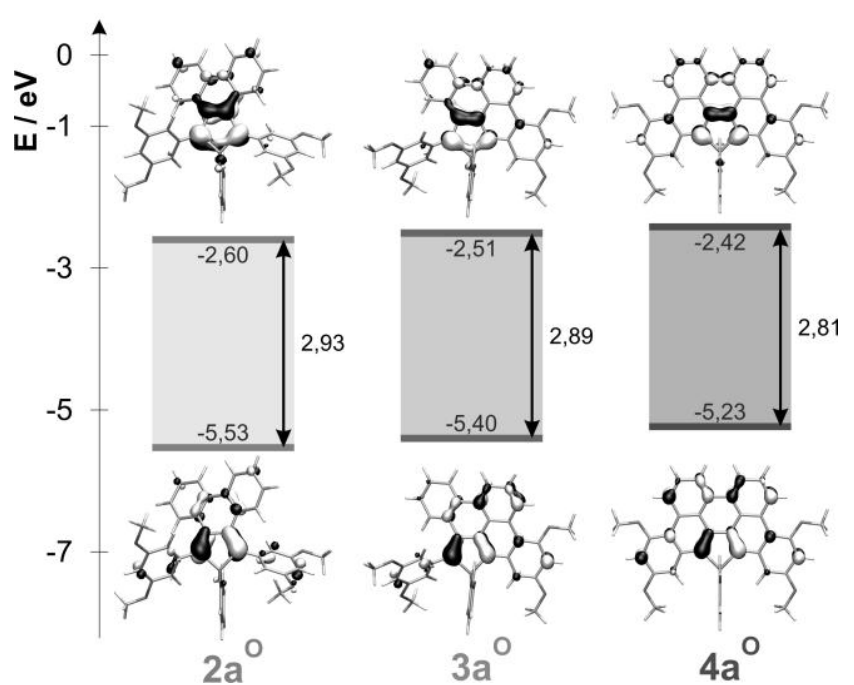

Figure 5 : B3LYP/6-31+G* frontier MO-s for $2 a^{\circ}-3 a^{\circ}-4 a^{\circ}$.

The changes in the electronic structure should be reflected in the aromaticity of the different rings. NICS values ${ }^{[22]}$ are collected in Table S7, and are presented in Figure 6, where the size of the circles is proportional to the NICS(1) value (NICS(0) shows a similar behaviour, see Figure S13), black representing antiaromatic, while grey aromatic ring current. It is known that phosphole-sulfides are slightly anti-aromatic, ${ }^{[23]}$ (in general, oxidation of second row heteroatoms decreases the aromaticity ${ }^{[24]}$ and accordingly the five-membered rings are antiaromatic for the entire series. More interestingly, the endocyclic 6-membered ring fused with the five-membered ring also became antiaromatic, throughout the entire series! With the increasing extent of the conjugation, the antiaromaticity shows some increase throughout the series $2 a^{\mathrm{s}}-\mathbf{3} a^{\mathrm{s}}-\mathbf{4} a^{\mathrm{s}}$, although the values remain small, e.g. in case of the NICS(1) value for the endocyclic 6-membered ring is +3.0 . To understand the slight antiaromaticity of the endocyclic 6-membered ring it is worth noting that the central ring of phenanthrene (which is in the position of the endocyclic 6 -membered ring of $2 a^{S}-3 a^{S}-4 a^{s}$ ), has a reduced NICS value ${ }^{[22]}$ with respect to the outer rings in accordance with Clar's rule. ${ }^{[25 c]}$ In the case of triphenylene, the central ring was shown to exhibit a slightly negative $\operatorname{NICS}(0)$ value only, while the central ring of coronene has a slightly positive NICS(0) value. ${ }^{[22 a, 25]}$ Nevertheless, it is rare among all carbon PAHs that antiaromatic (positive) NICS values are reported, although corner rings in giant hexagonal PAHs exhibit significant $\mathrm{NICS}(0)$ antiaromaticity. ${ }^{[26]}$ The two rings showing NICS antiaromaticity have also relatively low Bird index ${ }^{[27]}$ and $\mathrm{BDSHRT}^{[28]}$ values (eg. See the values for the endocyclic ring compared with the outer rings in Table S5-S7).

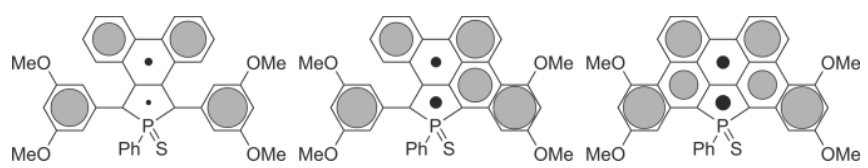

Figure 6 : Schematical representation of the NICS (1) values for $6 a^{s}-7 a^{s}-8 a^{s}$. Black represents antiaromatic, while grey aromatic ring current, the size of the ring is proportional to the calculated shielding.
Self-assembly in solution and in solid state, OLEDs. Since a large number of self-assembling organic molecules and especially PAHs have the ability to form non-emissive aggregates in solid state, we studied the aggregation of different dibenzophosphapentaphenes and its effect on their emission properties.

First, we have investigated the self-assembling features of compounds $\mathbf{2} \mathbf{b}^{\mathbf{S}}$ and $\mathbf{4} \mathbf{b}^{\mathbf{S}}$ in solution by using concentration dependent ${ }^{1} \mathrm{H}$ NMR experiments in $\mathrm{CDCl}_{3}$ as solvent. The ${ }^{1} \mathrm{H}$ NMR spectra of $\mathbf{2} \mathbf{b}^{\mathbf{S}}$ show no appreciable shift of the aromatic and aliphatic resonances in the concentration range used (Figure S14). In contrast, this is not the case for compound $\mathbf{4} \mathbf{b}^{\mathbf{S}}$ that exhibits a clear upfield shift of most of aromatic resonances upon increasing the concentration (Figure S15). This shielding effect, also observed in the aliphatic region, is diagnostic of the supramolecular interaction between the molecules $4 b^{\mathbf{s}}$. The variation of the chemical shifts upon increasing the concentration can be fitted to the isodesmic or equal- $K$ model to yield low values for the binding constant $K_{a}$ (Figure S15, right). ${ }^{[29]}$ This calculated low value of $K_{a}$ is not surprising considering that chloroform is a very good solvent to solubilize our compounds. ${ }^{[30]}$ The larger $\pi$-surface present in P-containing $\mathrm{PAH} \mathbf{4 b}^{\mathbf{s}}$ in comparison to $\mathbf{2} \mathbf{b}^{\mathbf{s}}$ accounts for the difference observed in the aggregation studies developed in solution. The pyramidal geometry of the P-atom impedes an efficient $\pi-\pi$ stacking of the aromatic rings of the investigated compounds. However, the calculated $K_{a}$ values are in good correlation with those previously reported for some other PAHs like hexa-peri-benzocoronenes. ${ }^{[31]}$

The differences in the self-assembly of compounds $2 \mathbf{b}^{\mathbf{s}}$ and $4 b^{S}$ also affect the generation of organized structures. Thus, a low diffusion of non-solvent vapors on a chloroform solution of compound $\mathbf{2} \mathbf{b}^{\mathbf{s}}$ results in the formation of an amorphous material. On the contrary, the compound $\mathbf{4} \mathbf{b}^{\mathbf{s}}$ is a highly crystalline material and it can easily be obtained by a slow diffusion of acetonitrile vapors on a chloroform solution. The SEM images of aggregates obtained from $\mathbf{4} \mathbf{b}^{\mathbf{S}}$ show lamellar structures with welldefined edges (Figure S16). The X-ray data obtained from this compound $\mathbf{4} \mathbf{b}^{\mathbf{s}}$ allows elaborating a model that could justify this supramolecular organization. The cooperation of $\mathrm{C}-\mathrm{H} \cdots \pi, \pi-$ stacking and van der Waals interactions between the lateral hexyloxy chains can explain the growing of the aggregates (Figure S4). The upfield shifts observed in the concentration dependent ${ }^{1} \mathrm{H}$ NMR experiments are in good agreement with the operation of these non-covalent interactions.

We have also investigated the emission properties of $2 a^{\mathbf{s}}$ and $4 a^{S}$ in acetone/water mixtures with increasing water fractions, a strategy that allows forming micro- or nanoaggregates in solution. As expected for PAH analogues, the emission of $4 a^{\mathbf{s}}$ is quenched upon aggregation (Figure 7). To the contrary, the emission of $2 \mathbf{a}^{\mathbf{s}}$ was enhanced by one order of magnitude once a specific water content was reached (acetone-water: 3-7, Figure 7). ${ }^{[32]}$ This phenomenon, referring like aggregation-induced emission (AIE), is linked with the restriction of internal rotations, which are responsible for quenching the luminescence in the non-aggregated state. ${ }^{[33}$ ] The absence of intermolecular interactions in the X-ray diffraction structure confirmed that the 
chromophores $2 \mathrm{a}^{\mathrm{s}}$ are independent in the solid state. This behaviour has already been observed on related siloles and phospholes. This opposite behaviour (Aggregation Quenched Emission vs AIE) between $2 a^{\mathbf{S}}$ and $4 a^{\mathrm{S}}$ illustrates again that these molecules have markedly different properties and show the pertinence of fusing phosphole in a PAH structure in order to modify its properties.

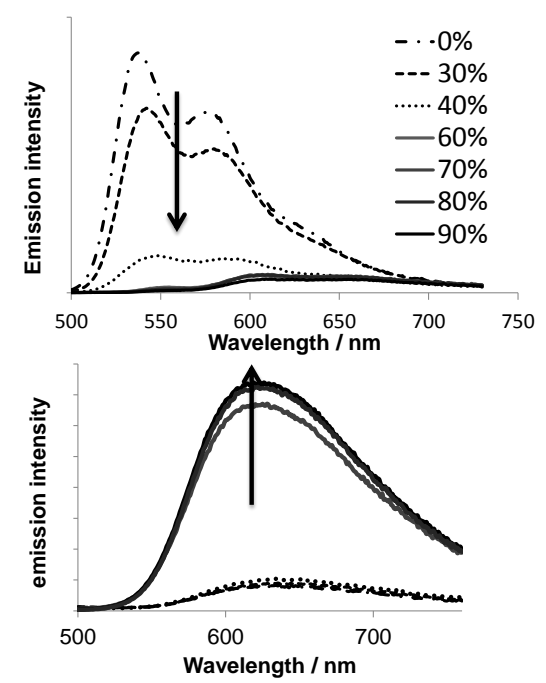

Figure 7 : Evolution of emission intensity of $4 a^{s}$ (upper) and $2 a^{s}$ (lower) (c = $5.10^{-5} \mathrm{M}$ ) in acetone/water (water percentage is indicated in legend) mixtures with increasing water content.

Aggregation induced-emission experiments showed that $4 a^{\mathbf{s}}$ is non-emiting in the aggregated state. This observation was extended to solid-state since no photoluminescence was observed on a thin film of $4 \mathbf{a}^{\mathrm{s}}$ sublimed on a glass substrate. However, as those compounds appeared to be highly emissive in the diluted solution (vide supra) and possess suitable redox properties, it was thus decided to study the electroluminescence of this family of compounds as dopant in a matrix. ${ }^{[34]}$ This technique is of particular interest since a careful choice of dopant and matrix emiting complementary colors leads to the preparation of WOLED devices. Since the compound $4 \mathbf{a}^{\mathbf{S}}$ is thermally stable (Table 2), it was co-sublimed with two different blue matrices (2,2'-diphenylvinyl) biphenyl, DPVBi (device A) and $\mathrm{N}, \mathrm{N}^{\prime}$-diphenyl-N,N'-bis (1-naphthylphenyl)-1,1'-biphenyl-4,4'diamine, $\alpha$-NPB (device B) for the construction of the active layer (EM) in OLEDs (Table 3). First, we developed a multilayer OLED on a glass substrate having a classical multilayered configuration : indium tin oxide (ITO) / copper phthalocyanine (CuPc) $(10 \mathrm{~nm}) / \mathrm{N}, \mathrm{N}^{\prime}$-diphenyl-N,N'-bis (1-naphthylphenyl) -1,1'biphenyl-4,4'-diamine ( $\alpha$-NPB) $(50 \mathrm{~nm}) / \mathrm{EM}(15 \mathrm{~nm}) / 4,4$ '-bis (2,2'-diphenylvinyl) biphenyl (DPVBi) $(35 \mathrm{~nm}) /$ bathocuproine (BCP) $(10 \mathrm{~nm}) /$ tris(8-hydroxyquinolinato)aluminium $\left(\mathrm{Alq}_{3}\right)$ (10 $\mathrm{nm})$ / LiF (1.2 nm) /Al (100 nm) (see Figure S17). The electroluminescence (EL) spectrum of devices $\mathbf{A}$ and $\mathbf{B}$ having similar doping rate $(2.8 \%)$ presents the dual emission of the blueemiting matrix ( $\lambda_{E L 1}=448 \mathrm{~nm}$ for device $A$ and $\lambda_{E L 1}=456 \mathrm{~nm}$ for device $B)$ and the phosphorus based dopant $\left(\lambda_{E L 2}=556 \mathrm{~nm}\right.$ for device $\mathbf{A}$ and $\lambda_{E L 2}=548 \mathrm{~nm}$ for device $\mathbf{B}$ ) leading to an orange- white emision as evidenced by the CIE coordinates (Table 3). The EL spectra match very well with the photoluminescence spectra recorded for the matrix and the dopant in thin film, showing that the EL emission bands originates from the blue emitter and the P-luminophore (see Figure 8). The two devices present a small turn-on voltage with moderate current and power efficiencies (Table 3). It can be noticed that the OLED performances of device $\mathbf{B}$ were slightly better than those of device $\mathbf{A}$ (see Table 3), so it was decided to test the effect of doping rate with the $\alpha$-NPB matrix. The doping rate of $4 a^{\mathrm{S}}$ was gradually decreased from $5.5 \%$ to $0.6 \%$ (device B-E) allowing to increase the contribution of $\alpha$-NPB emission and to tune the CIE chromaticity coordinates from the orange region (device $\mathbf{C}$ ) to the blue region (device $\mathbf{E}$ ) (Table 3 ). The case of device $\mathbf{D}$ was particularly interesting since the $\mathrm{CIE}$ chromaticity coordinates are in the white area $(x=0.32 ; y=0.37)$. The turn-on voltage of device $\mathbf{D}$ is quite low (5.5 V) and it exhibits an EQE of $1.7 \%$, a brightness of $1122 \mathrm{~cd} . \mathrm{m}^{-2}$ and a power efficiency of $0.96 \mathrm{Im} . \mathrm{W}^{-1}$ at $30 \mathrm{~mA} / \mathrm{cm}^{2}$ (Table 3). Furthermore, the increase of the current density up to $180 \mathrm{~mA} \cdot \mathrm{cm}^{-2}$ does not impact the electroluminescent spectrum, indicating a good device stability (see Figure 8). For increasing the performance of the OLED, we decided to modify the multilayered structure by changing the electron transport layer $\left(\mathrm{Alq}_{3}\right)$ and the hole blocking layer (BCP) by 1,3,5-tris(N-phenylbenzimiazole-2-yl)benzene (TPBi) which is known as a good electron transporting and hole blocking material with the HOMO level of $6.2 \mathrm{eV}$ and the LUMO level of $2.7 \mathrm{eV} .^{[35]}$ The better fit between the energetic level of TPBi and DPVBi is believed to favor the charge balance and to be the reason of the improvement of the performances. The power and current efficiencies now reach values of $1.40 \mathrm{Im} . \mathrm{W}^{-1}$ and $4.40 \mathrm{~cd} . \mathrm{A}^{-1}$ respectively, at $30 \mathrm{~mA} / \mathrm{cm}^{2}$ (device $\mathbf{F}$, Table 3). The compound $4 a^{\circ}$ was also considered as orange emitter for OLEDs since it presents similar physical and thermal properties as the compound $4 \mathrm{a}^{\mathrm{s}}$ (Table 2). For example, white emission can be obtained by doping the $\alpha$-NPB matrix with $0.8 \%$ of compound $4 a^{\circ}$. The performance (Device $\mathbf{G}$, Table 3 ) of this WOLED is very satisfying with a brightness of $728 \mathrm{~cd} \cdot \mathrm{m}^{-2}$ at $30 \mathrm{~mA} / \mathrm{cm}^{2}$. All these results demonstrate that phosphorus-containing $\mathrm{PAH}$ emitters can be used for the development of efficient fluorescent OLEDs.

\section{Conclusions}

In conclusion, we prepared P-containing PAHs. We showed that the cyclization around the phosphole ring allows to fine tune the electronic properties of these compounds as evidenced by UV-vis absorption, emission, electrochemistry and theoretical calculation. It is of particular interest that computational study showed that the phosphole MO's still prevail in the highly delocalized PAH structure and that the presence of the P-atom impacts the whole structure. Most notably, the antiaromaticity of oxidized phospholes is extended over the endocyclic six membered ring. Self-assembly in solution also appears to significantly impact the photophysical properties of this family of compounds. Finally, by doping a blue emitting matrix with these 
P-containing PAHs, white light emission in multi-layered OLED device was achieved. These first results of incorporation into opto-electronic device show the potential of these compounds for opto-electronic application.

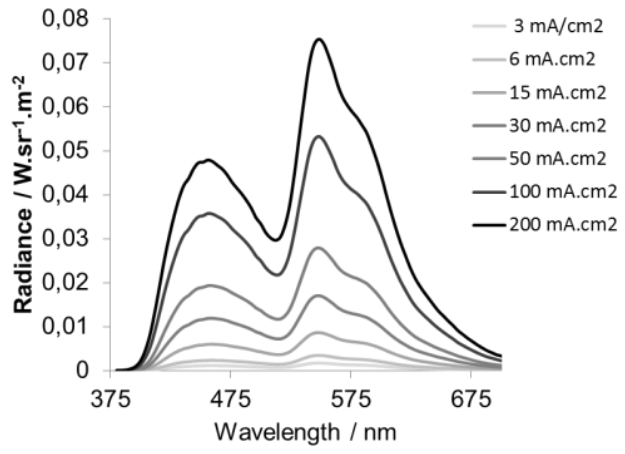

Figure 8. Effect of current density on the electroluminescence of device D.

Table 3. EL performance of devices as function of the device structure and of the doping rate..

\begin{tabular}{|c|c|c|c|c|c|c|c|c|}
\hline Device & $\begin{array}{c}\text { EML Doping rate } \\
\text { [wt, \%] }\end{array}$ & $\begin{array}{c}\mathrm{V}_{\mathrm{on}}^{[\mathrm{a}]} \\
{[\mathrm{V}]}\end{array}$ & $\begin{array}{c}\mathrm{B}_{30}{ }^{[\mathrm{b}]} \\
{\left[\mathrm{cd} \cdot \mathrm{m}^{-2}\right]}\end{array}$ & $\begin{array}{c}\eta_{30}^{[b]} \\
{[\%]}\end{array}$ & $\begin{array}{c}\text { Power } \\
\text { Efficiency }\end{array}$ & Current efficiency ${ }^{[b]}$ & $X^{[d]}$ & $Y^{[d]}$ \\
\hline A & DPVBi : $\mathbf{4} \mathbf{a}^{\mathbf{S}}(2.8)$ & 4.86 & 905 & 1.18 & 0.71 & 2.96 & 0.42 & 0.44 \\
\hline B & $\alpha-\mathrm{NPB}: \mathbf{4 a}^{\mathbf{s}}(2.8)$ & 5.81 & 1062 & 1.46 & 0.90 & 3.53 & 0.41 & 0.43 \\
\hline C & $\alpha-\mathrm{NPB}: \mathbf{4} \mathbf{a}^{\mathbf{s}}(5.5)$ & 5.71 & 906 & 1.30 & 0.77 & 3.03 & 0.45 & 0.44 \\
\hline D & $\alpha-\mathrm{NPB}: \mathbf{4 a}^{\mathrm{s}}(1.1)$ & 5.55 & 1122 & 1.67 & 0.96 & 3.69 & 0.32 & 0.37 \\
\hline E & $\alpha-\mathrm{NPB}: \mathbf{4} \mathbf{a}^{\mathbf{s}}(0.6)$ & 6.04 & 916 & 1.56 & 0.72 & 2.99 & 0.26 & 0.31 \\
\hline $\mathbf{F}$ & $\alpha-\mathrm{NPB}: 4 \mathrm{a}^{\mathrm{s}}(1.2)^{\mathrm{c}}$ & 5.19 & 1308 & 2.10 & 1.40 & 4.40 & 0.29 & 0.34 \\
\hline G & $\alpha-\mathrm{NPB}: \mathbf{4 a}^{\mathbf{0}}(0.8)$ & 6.06 & 728 & 1.19 & 0.61 & 2.40 & 0.32 & 0.35 \\
\hline $\mathbf{H}$ & $\alpha-\mathrm{NPB}: \mathbf{4 a}^{\mathbf{0}}(1.3)^{\mathrm{c}}$ & 5.35 & 1943 & 2.87 & 1.83 & 6.58 & 0.37 & 0.39 \\
\hline
\end{tabular}

[a] Turn-on voltage at which emission becomes detectable $\left(0.1 \mathrm{~cd} / \mathrm{m}^{2}\right) .{ }^{[\mathrm{b}]}$ Measured at $30 \mathrm{~mA} / \mathrm{cm}^{2}$. ${ }^{[\mathrm{c}]}$ OLEDs with the alternative TPBi based configuration. ${ }^{[\mathrm{d}]}$ CIE coordinates 


\section{Experimental Section}

General Procedures. All experiments were performed under an atmosphere of dry argon using standard Schlenk techniques. Commercially available reagents were used as received without further purification. Solvents were freshly purified using MBRAUN SPS-800 drying columns. Irradiation reactions were conducted using a Heraeus TQ 150 mercury vapor lamp. Separations were performed by gravity column chromatography on basic alumina (Aldrich, Type 5016A, 150 mesh, $58 \AA$ ) or silica gel (Merck Geduran 60, 0.063-0.200 mm). ${ }^{1} \mathrm{H},{ }^{13} \mathrm{C}$, and ${ }^{31} \mathrm{P}$ NMR spectra were recorded on a Bruker AM300, AM400, AM500. ${ }^{1} \mathrm{H}$ and ${ }^{13} \mathrm{C}$ NMR chemical shifts were reported in parts per million (ppm) relative to $\mathrm{Me}_{4} \mathrm{Si}$ as external standard. Assignment of proton and carbon atoms is based on COSY, HMBC, HMQC and DEPT-135 experiments. High-resolution mass spectra were obtained on a Varian MAT 311 or ZabSpec TOF Micromass instrument at CRMPO, University of Rennes 1. Elemental analyses were performed by the CRMPO, University of Rennes 1. Compounds $1 \mathrm{a}, \mathbf{2} \mathrm{a}^{\mathrm{s}}, \mathbf{3} \mathrm{a}^{\mathrm{s}}, \mathbf{4 a ^ { \mathrm { s } }}, \mathbf{4 a ^ { 0 }}$, were synthesized according to published procedure. ${ }^{[14]} \mathrm{UV}$-Visible spectra were recorded at room temperature on a VARIAN Cary 5000 spectrophotometer. The UVVis-NIR emission and excitation spectra measurements were recorded on a FL 920 Edimburgh Instrument equipped with a Hamamatsu R550973 photomultiplier for the NIR domain (300-1700 nm) and corrected for the response of the photomultiplier. Quantum yields were calculated relative to fluorescein $(\phi=0.90$ in $\mathrm{NaOH} 0.1 \mathrm{~N})$. The electrochemical studies were carried out under argon using an Eco Chemie Autolab PGSTAT 30 potentiostat for cyclic voltammetry with the three-electrode configuration: the working electrode was a platinum disk, the reference electrode was a saturated calomel electrode and the counter-electrode a platinum wire. All potential were internally referenced to the ferrocene/ ferrocenium couple. For the measurements, concentrations of $10^{-3} \mathrm{M}$ of the electroactive species were used in freshly distilled and degassed dichloromethane and $0.2 \mathrm{M}$ tetrabutylammonium hexafluorophosphate. Thermogravimetric analysis were performed by using a Mettler-Toledo TGA-DSC-1 apparatus under dry nitrogen flow at a heating rate of $10{ }^{\circ} \mathrm{C} / \mathrm{min}$. Infrared spectra were obtained on a Bruker IFS28 FT-IR spectrometer $\left(400-4000 \mathrm{~cm}^{-1}\right)$. Raman spectra of the solid samples were obtained by diffuse scattering on the same apparatus and recorded in the $100-3300 \mathrm{~cm}^{-1}$ range (Stokes emission) with a laser excitation source at $1064 \mathrm{~nm}(25 \mathrm{~mW})$ and a quartz separator with a FRA 106 detector.

Details of the $X$-ray crystallography study: X-ray crystallographic data for $4 \mathrm{a}^{\mathrm{S}}$ (CCDC 861180) was previously reported. ${ }^{14}$ Single crystals of $2 \mathrm{a}^{\mathbf{s}}$, $3 a^{\mathbf{s}}$ and $\mathbf{4} b^{S}$ suitable for X-Ray crystal analyses were obtained by slow diffusion of vapors of pentane into dichloromethane solutions. Single crystal data collection were performed at $150 \mathrm{~K}$ with an APEX II BrukerAXS (Centre de Diffractométrie, Université de Rennes 1, France) with Mo- $K \alpha$ radiation $(\lambda=0.71073 \AA)$. Reflections were indexed, Lorentzpolarization corrected and integrated by the DENZO program of the KappaCCD software package. The data merging process was performed using the SCALEPACK program. ${ }^{[36]}$ Structure determinations were performed by direct methods with the solving program SIR97, ${ }^{[37]}$ that revealed all the non-hydrogen atoms. SHELXL program ${ }^{[38]}$ was used to refine the structures by full-matrix least-squares based on $F^{2}$. All nonhydrogen atoms were refined with anisotropic displacement parameters. Hydrogen atoms were included in idealised positions and refined with isotropic displacement parameters. Single crystals of all these derivatives were always coated in paratone oil once removed from the mother solution, mount at low temperature on the diffractometer goniometer and X-ray data collection were performed at low temperature. Atomic scattering factors for all atoms were taken from International Tables for X-ray Crystallography. ${ }^{[39]}$ CCDC reference numbers 1014349,1014350 and 1014351, contain the supplementary crystallographic data for derivatives $2 a^{s}, 3 a^{s}$ and $4 b^{s}$ respectively.
Device fabrication and characterization: EL devices, based on a multilayer structure have been fabricated onto patterned ITO coated glass substrates from PGO CEC020S (thickness: $100 \mathrm{~nm}$ and sheet resistance: less of $20 \Omega / \mathrm{m}$ ). The organic materials (from Aldrich and Syntec) are deposited onto the ITO anode by sublimation under high vacuum $\left(<10^{-6}\right.$ Torr) at a rate of $0.2-0.3 \mathrm{~nm} / \mathrm{s}$. The common structure of all the devices is the following: a thin layer (10 nm thick) of copper phtalocyanine (CUPc) is used as hole injection layer (HIL) and $50 \mathrm{~nm}$ of N,N'-diphenyl-N,N'-bis(1-naphthylphenyl)-1,1'-biphenyl-4,4'-diamine $\quad(\alpha$ NPB) as hole transporting layer (HTL). The emitting layer consists of 15 $\mathrm{nm}$ thick film of $(\alpha-\mathrm{NPB})$ or DPVBi doped P-containing PAH. The doped layer is obtained by co-evaporation of the two compounds and the doping rate is controlled by tuning the evaporation rate of each material. $A$ thin layer of bathocuproine (BCP) $(10 \mathrm{~nm})$ is used as hole blocking layer. $\mathrm{Alq}_{3}$ $(10 \mathrm{~nm})$ is used as electron transporting layer (ETL). TPBI $(20 \mathrm{~nm})$ is used as alternative ETL/hole blocking layer. Finally, a cathode consisting of $1.2 \mathrm{~nm}$ of LiF capped with $100 \mathrm{~nm}$ of $\mathrm{Al}$ is deposited onto the organic stack. The entire device is fabricated in the same run without breaking the vacuum. In this study, the thicknesses of the different organic layers were kept constant for all the devices. The active area of the devices defined by the overlap of the ITO anode and the metallic cathode was 0.3 $\mathrm{cm}^{2}$. The current-voltage-luminance (I-V-L) characteristics of the devices were measured with a regulated power supply (Laboratory Power Supply EA-PS 3032-10B) combined with a multimeter and a $1 \mathrm{~cm}^{2}$ area silicon calibrated photodiode (Hamamatsu). The spectral emission was recorded with a SpectraScan PR650 spectrophotometer. All the measurements were performed at room temperature and at ambient atmosphere with no further encapsulation of devices.

Computational details: All calculations have been carried out with the Gaussian 09 program package ${ }^{[40]}$ Full geometry optimization was performed for all molecules at the B3LYP/6-31+G* level, ${ }^{[41]}$ and harmonic vibrational frequencies were calculated at the same level to establish the nature of the obtained stationary point, for minima no negative eigenvalue of the Hessian was present. All possible rotational structures $\left(2 a^{s}, 3 a^{s}\right.$ : methoxy and phenyl rotations, $4 a^{s}$ methoxy rotations) have been investigated for $2 a^{s}, 3 a^{s}$ and $4 a^{s}$, the most stable ones being those obtained also by X-ray crystallography. The Kohn-Sham HOMO-LUMO gap is nearly unchanged for the different conformers. Further calculations on $2 a^{\circ}, 3 a^{\circ}, 4 a^{\circ}$ have been carried out only on the rotamer which turned out to be the most stable for the respective thiooxidized compounds. Raman visualisations have been carried out with the Molden ${ }^{[42] \text {, }}$ molecular orbital visualisations with the VMD package. ${ }^{43}$

Experimental part: Synthesis of 1b. 2,2'-diethynylbiphenyl (380 mg, 3.7 mmol, 1 eq.) and 1-bromo-3,5-hexyloxybenzene (2.0 g, 3 eq.) were dissolved in $50 \mathrm{~mL}$ of THF-NEt $3(1: 2, \mathrm{v} / \mathrm{v})$. The solution was then sparged with argon for $15 \mathrm{~min}$ and $\mathrm{Pd}\left(\mathrm{PPh}_{3}\right)_{4}(222 \mathrm{mg}, 0.1$ eq.) was added and the solution was refluxed for $20 \mathrm{~h}$. After cooling down to room temperature (RT), the mixture was filtrated and diethylether $(150 \mathrm{~mL})$ was added. The organic layer was washed with saturated $\mathrm{NH}_{4} \mathrm{Cl}$ solution, then with water, dried over $\mathrm{MgSO}_{4}$ and the solvents were evaporated. The crude was purified by chromatography on silica gel using heptane:ethyl acetate $(98: 2, \mathrm{v} / \mathrm{v})$ as eluent to afford $\mathbf{1 b}$ as transparent oil (1.07 g, $75 \%) .{ }^{1} \mathrm{H}$ NMR (400 MHz, $\left.\mathrm{CDCl}_{3}\right): \delta 0.90\left(\mathrm{t},{ }^{3} \mathrm{~J}(\mathrm{H}, \mathrm{H})=6 \mathrm{~Hz}\right.$, $\left.12 \mathrm{H}, H_{16}\right), 1.2-1.5\left(\mathrm{~m}, 24 \mathrm{H}, \mathrm{H}_{13-15}\right), 1.7-1.8\left(\mathrm{~m}, 8 \mathrm{H}, \mathrm{H}_{12}\right), 3.85\left(\mathrm{t}, 8 \mathrm{H},{ }^{3} J\right.$ $\left.(\mathrm{H}, \mathrm{H})=6 \mathrm{~Hz}, \mathrm{H}_{11}\right) ; 6.34-6.40\left(\mathrm{~m}, 6 \mathrm{H}, \mathrm{CH}_{\text {phenyl }}\right) ; 7.37\left(\mathrm{ddd}, 2 \mathrm{H},{ }^{3} \mathrm{~J}(\mathrm{H}, \mathrm{H})=\right.$ $\left.7 \mathrm{~Hz},{ }^{3} \mathrm{~J}(\mathrm{H}, \mathrm{H})=7 \mathrm{~Hz},{ }^{4} \mathrm{~J}(\mathrm{H}, \mathrm{H})=1.2 \mathrm{~Hz}, \mathrm{CH}_{\text {phenyl }}\right) ; 7.42$ (ddd, $2 \mathrm{H},{ }^{3} \mathrm{~J}(\mathrm{H}, \mathrm{H})$ $\left.=8 \mathrm{~Hz},{ }^{3} \mathrm{~J}(\mathrm{H}, \mathrm{H})=8 \mathrm{~Hz},{ }^{4} \mathrm{~J}(\mathrm{H}, \mathrm{H})=1.2 \mathrm{~Hz}, \mathrm{CH}_{\text {phenyl }}\right) ; 7.54\left(\mathrm{dd}, 2 \mathrm{H},{ }^{3} \mathrm{~J}\right.$ $\left.(\mathrm{H}, \mathrm{H})=7 \mathrm{~Hz},{ }^{4} \mathrm{~J}(\mathrm{H}, \mathrm{H})=1.2 \mathrm{~Hz}, \mathrm{C} H_{\text {phenyl }}\right), 7.66\left(\mathrm{dd}, 2 \mathrm{H},{ }^{3} \mathrm{~J}(\mathrm{H}, \mathrm{H})=7 \mathrm{~Hz}\right.$, $\left.{ }^{4} \mathrm{~J}(\mathrm{H}, \mathrm{H})=1.2 \mathrm{~Hz}, \mathrm{CH}_{\text {phenyl }}\right) \cdot{ }^{13} \mathrm{C} \operatorname{NMR}\left(75 \mathrm{MHz}, \mathrm{CDCl}_{3}\right): \delta 14.1\left(\mathrm{~s}, \mathrm{C}_{16}\right)$, $22.6\left(\mathrm{~s}, \mathrm{C}_{15}\right), 25.6\left(\mathrm{~s}, \mathrm{C}_{14}\right), 29.1\left(\mathrm{~s}, \mathrm{C}_{13}\right), 31.6\left(\mathrm{~s}, \mathrm{C}_{12}\right), 68.1\left(\mathrm{~s}, \mathrm{O}-C_{11}\right)$;

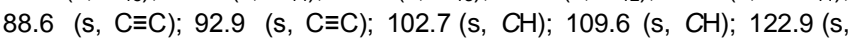
$\left.C_{\text {quat }}\right) ; 124.6\left(\mathrm{~s}, C_{\text {quat }}\right) ; 127.3(\mathrm{~s}, \mathrm{CH}) ; 127.6(\mathrm{~s}, \mathrm{CH}) ; 130.4(\mathrm{~s}, \mathrm{CH})$; $131.9(\mathrm{~s}, \mathrm{CH}) ; 143.4\left(\mathrm{~s}, C_{\text {quat }}\right) ; 159.9$ (s, $\left.\mathrm{COCH}_{2^{-}}\right)$. HR-MS (ESI, $\mathrm{CH}_{2} \mathrm{Cl}_{2} / \mathrm{MeOH}, 95 / 5, \mathrm{~m} / \mathrm{z}$ ): [M] ${ }^{+}$calcd for $\mathrm{C}_{52} \mathrm{H}_{66} \mathrm{O}_{4}, 754.4961$; found 754.4832. Anal. Calcd. for $\mathrm{C}_{52} \mathrm{H}_{66} \mathrm{O}_{4}$ : C, 82.71, $\mathrm{H}, 8.81$; Found: $\mathrm{C}, 82.44$, $\mathrm{H}, 8.78$. 
Synthesis of $2 \mathrm{a}^{\circ}$. Compound $5 \mathrm{a}(220 \mathrm{mg}, 0.46 \mathrm{mmol}, 1 \mathrm{eq}$.) and $\mathrm{Cp}_{2} \mathrm{ZrCl}_{2}$ (135 mg, 1 eq.) were dissolved in THF $(20 \mathrm{~mL})$. n-BuLi (2.5 M, $0.4 \mathrm{~mL}, 2.1 \mathrm{eq}$.) was added dropwise at $-78^{\circ} \mathrm{C}$. The solution was warmed at room temperature (RT) and stirred overnight. To this solution was added $\mathrm{PhPCl}_{2}(0.08 \mathrm{~mL}, 1.2$ eq. $)$ at $-78^{\circ} \mathrm{C}$. The solution was warmed at RT and stirred for $24 \mathrm{~h}$. The solution was filtered on basic alumina, washed with THF and the solvent were evaporated. The orange precipitate of phosphole $\left({ }^{31} \mathrm{P} \mathrm{NMR}\left(80 \mathrm{MHz}, \mathrm{CDCl}_{3}\right): \delta=+31 \mathrm{ppm}\right)$ was dissolved in DCM $(30 \mathrm{~mL})$, an excess of $\mathrm{NalO}_{4}$ was added to the solution and the solution was stirred for $2 \mathrm{~h}$. The solution was filtered and the solvent was evaporated. The crude was purified by chromatography on silica gel using heptane:ethyl acetate $(1: 1, \mathrm{v} / \mathrm{v})$ as eluent to afford $6 \mathrm{a}^{\circ}$ as a red solid $(90 \mathrm{mg}, 32 \%) .{ }^{1} \mathrm{H}$ NMR $\left(400 \mathrm{MHz}, \mathrm{CDCl}_{3}\right): \delta 3.64(\mathrm{~s}, 12 \mathrm{H}$, $\left.\mathrm{OCH}_{3}\right) ; 6.35-6.40\left(\mathrm{~m}, 6 \mathrm{H}, \mathrm{H}_{2}\right.$ and $\left.\mathrm{H}_{4}\right) ; 6.99\left(\mathrm{ddd}, 2 \mathrm{H},{ }^{3} \mathrm{~J}(\mathrm{H}, \mathrm{H})=8 \mathrm{~Hz},{ }^{3} \mathrm{~J}\right.$ $\left.(\mathrm{H}, \mathrm{H})=8 \mathrm{~Hz},{ }^{4} \mathrm{~J}(\mathrm{H}, \mathrm{H})=1.2 \mathrm{~Hz}, \mathrm{H}_{7}\right) ; 7.33\left(\mathrm{ddd}, 2 \mathrm{H},{ }^{3} \mathrm{~J}(\mathrm{H}, \mathrm{H})=8 \mathrm{~Hz},{ }^{3} \mathrm{~J}\right.$ $\left.(\mathrm{H}, \mathrm{H})=8 \mathrm{~Hz},{ }^{4} \mathrm{~J}(\mathrm{H}, \mathrm{H})=1.2 \mathrm{~Hz}, \mathrm{H}_{8}\right) ; 7.40\left(\mathrm{~m}, 2 \mathrm{H}, \mathrm{H}_{\text {meta }}\right) ; 7.49(\mathrm{~m}, 1 \mathrm{H}$, $\left.\mathrm{H}_{\text {para }}\right) ; 7.57\left(\mathrm{~d}, 2 \mathrm{H},{ }^{3} \mathrm{~J}(\mathrm{H}, \mathrm{H})=8 \mathrm{~Hz}, \mathrm{H}_{6}\right), 7.86\left(\mathrm{~m}, 2 \mathrm{H}, \mathrm{H}_{\text {ortho }}\right) ; 7.92(\mathrm{~d}, 2 \mathrm{H}$, $\left.{ }^{3} J(\mathrm{H}, \mathrm{H})=8 \mathrm{~Hz}, \mathrm{H}_{9}\right) \cdot{ }^{13} \mathrm{C}$ NMR $\left(75 \mathrm{MHz}, \mathrm{CDCl}_{3}\right): \delta 55.3\left(\mathrm{~s}, \mathrm{OCH}_{3}\right) ; 101.1$ $\left(\mathrm{d}, J(P, C)=2 \mathrm{~Hz}, \mathrm{C}_{4}\right) ; 105.6\left(\mathrm{~d}, J(\mathrm{P}, \mathrm{C})=4 \mathrm{~Hz}, \mathrm{C}_{2}\right) ; 124.0$ (s, $\left.\mathrm{C}_{9}\right) ; 127.2$ $\left(\mathrm{d}, J(\mathrm{P}, \mathrm{C})=96 \mathrm{~Hz}, \mathrm{C}_{\mathrm{ipso}}\right) ; 127.9\left(\mathrm{~s}, \mathrm{C}_{7}\right) ; 128.4\left(\mathrm{~d}, J(\mathrm{P}, \mathrm{C})=20 \mathrm{~Hz}, \mathrm{C}_{5}\right)$; $129.0\left(\mathrm{~d}, J(\mathrm{P}, \mathrm{C})=12 \mathrm{~Hz}, \mathrm{C}_{\text {meta }}\right) ; 130.0\left(\mathrm{~s}, \mathrm{C}_{6}\right) ; 130.8\left(\mathrm{~s}, \mathrm{C}_{8}\right) ; 131.5(\mathrm{~d}$, $\left.J(P, C)=10 \mathrm{~Hz}, \mathrm{C}_{\text {ortho }}\right) ; 132.2\left(\mathrm{~d}, J(\mathrm{P}, \mathrm{C})=3 \mathrm{~Hz}, \mathrm{C}_{\text {para }}\right) ; 132.3(\mathrm{~d}, J(\mathrm{P}, \mathrm{C})=$ $\left.94 \mathrm{~Hz}, \mathrm{C}_{\alpha}\right) ; 133.8\left(\mathrm{~d}, \mathrm{~J}(\mathrm{P}, \mathrm{C})=1 \mathrm{~Hz}, \mathrm{C}_{10}\right) ; 136.2\left(\mathrm{~d}, \mathrm{~J}(\mathrm{P}, \mathrm{C})=8 \mathrm{~Hz}, \mathrm{C}_{1}\right)$; $142.2\left(\mathrm{~d}, J(\mathrm{P}, \mathrm{C})=28 \mathrm{~Hz}, \mathrm{C}_{\beta}\right) ; 161.5\left(\mathrm{~s}, \mathrm{C}_{3}\right) .{ }^{31} \mathrm{P}$ NMR $\left(75 \mathrm{MHz}, \mathrm{CDCl}_{3}\right)$ : $\delta+39.2$ (s). HRMS (ESI, $\mathrm{CH}_{2} \mathrm{Cl}_{2} / \mathrm{MeOH}, 9 / 1, \mathrm{~m} / \mathrm{z}$ ): $[\mathrm{M}+\mathrm{H}]^{+}$calcd. for $\mathrm{C}_{38} \mathrm{H}_{32} \mathrm{O}_{5} \mathrm{P}, 599.1982$; found 599.1966. Anal. Calcd. for $\mathrm{C}_{38} \mathrm{H}_{31} \mathrm{O}_{5} \mathrm{P}: \mathrm{C}$, 76.24, H, 5.22; Found: C, 75.95, H, 5.19.

Synthesis of $2 \boldsymbol{b}^{\boldsymbol{S}}$. To a $369 \mathrm{mg}(1.26 \mathrm{mmol}, 1.05$ eq.) solution of $\mathrm{Cp}_{2} \mathrm{ZrCl}_{2}$ in $25 \mathrm{~mL}$ of THF at $-80^{\circ} \mathrm{C}$ are added $1.1 \mathrm{~mL}$ of $n$-BuLi $(2.65$ $\mathrm{mmol}, 2.1 \mathrm{eq}$ ). The mixture warm up slowly to $-65^{\circ} \mathrm{C}$ and is cooling down again to $-80^{\circ} \mathrm{C}$. Then, $908 \mathrm{mg}$ of $\mathbf{1 b}(1.20 \mathrm{mmol}, 1.0 \mathrm{eq})$ in $10 \mathrm{~mL}$ of THF are slowly added. After $15 \mathrm{~h}$ at RT, $196 \mu \mathrm{L}$ of $\mathrm{PhPCl}_{2}(1.44 \mathrm{mmol}, 1.2 \mathrm{eq})$ are introduced in the mixture, at $-30^{\circ} \mathrm{C}$. After $10 \mathrm{~h}$, the solution is filtered on silica gel (eluent: dichloromethane) and solvents. The resulting orange oil is dissolved in dichloromethane $(25 \mathrm{~mL})$ and stirred for $2 \mathrm{~h}$ with an excess of $S_{8}$ in presence of triethylamine. After evaporation, the crude is dissolved in heptane and filtrated to remove the excess of $S_{8}$. Product is purified by chromatography on silica gel using ethyl acetate/heptane $(98: 2, \mathrm{v} / \mathrm{v})$ as eluent to afford $380 \mathrm{mg}$ of an orange oil $(\mathrm{Y}=35 \%) .{ }^{1} \mathrm{H}$ NMR $\left(300 \mathrm{MHz}, \mathrm{CDCl}_{3}\right): \delta 0.88\left(\mathrm{t}, 12 \mathrm{H},{ }^{3} \mathrm{~J}(\mathrm{H}, \mathrm{H})=6 \mathrm{~Hz}, \mathrm{H}_{16}\right), 1.16-1.47(\mathrm{~m}$, $\left.24 \mathrm{H}, \mathrm{H}_{13}, \mathrm{H}_{14}, \mathrm{H}_{15}\right) ; 1.65\left(\mathrm{~m}, 8 \mathrm{H}, \mathrm{H}_{12}\right) ; 3.50-4.20\left(\mathrm{~m}, 8 \mathrm{H}, \mathrm{H}_{11}\right) ; 5.70-6.00$ $\left(\mathrm{m}, 2 \mathrm{H}, \mathrm{H}_{2}\right) ; 6.39\left(\mathrm{~m}, 2 \mathrm{H}, \mathrm{H}_{4}\right) ; 6.80-6.95\left(\mathrm{~m}, 2 \mathrm{H}, \mathrm{H}_{2}\right) ; 7.00$ (ddd, $2 \mathrm{H}$, $\left.{ }^{3} \mathrm{~J}(\mathrm{H}, \mathrm{H})=8 \mathrm{~Hz},{ }^{3} \mathrm{~J}(\mathrm{H}, \mathrm{H})=8 \mathrm{~Hz},{ }^{4} \mathrm{~J}(\mathrm{H}, \mathrm{H})=1 \mathrm{~Hz}, \mathrm{H}_{7}\right) ; 7.36$ (ddd, $2 \mathrm{H}$, $\left.{ }^{3} \mathrm{~J}(\mathrm{H}, \mathrm{H})=8 \mathrm{~Hz},{ }^{3} \mathrm{~J}(\mathrm{H}, \mathrm{H})=8 \mathrm{~Hz},{ }^{4} \mathrm{~J}(\mathrm{H}, \mathrm{H})=1 \mathrm{~Hz}, \mathrm{H}_{8}\right) ; 7.40$ (m, 2H, $\mathrm{H}_{\text {meta }}$ ); $7.46\left(\mathrm{~m}, 1 \mathrm{H}, \mathrm{H}_{\text {para }}\right) ; 7.58\left(\mathrm{~d}, 2 \mathrm{H},{ }^{3} \mathrm{~J}(\mathrm{H}, \mathrm{H})=8 \mathrm{~Hz}, \mathrm{H}_{6}\right), 7.91$ (ddd, $2 \mathrm{H}$, $\left.{ }^{4} J(\mathrm{H}, \mathrm{H})=2 \mathrm{~Hz},{ }^{3} \mathrm{~J}(\mathrm{H}, \mathrm{H})=8 \mathrm{~Hz}, J(\mathrm{P}, \mathrm{H})=14 \mathrm{~Hz}, \mathrm{H}_{\text {ortho }}\right) ; 7.96\left(\mathrm{~d}, 2 \mathrm{H},{ }^{3} \mathrm{~J}\right.$ $\left.(\mathrm{H}, \mathrm{H})=8 \mathrm{~Hz}, \mathrm{H}_{9}\right) \cdot{ }^{13} \mathrm{C}$ NMR $\left(100 \mathrm{MHz}, \mathrm{CDCl}_{3}\right): \delta 14.2\left(\mathrm{~s}, \mathrm{C}_{16}\right) ; 22.7(\mathrm{~s}$, $\left.\mathrm{C}_{15}\right) ; 25.8\left(\mathrm{~s}, \mathrm{C}_{14}\right) ; 29.2\left(\mathrm{~s}, \mathrm{C}_{13}\right) ; 31.7\left(\mathrm{~s}, \mathrm{C}_{12}\right) ; 68.2\left(\mathrm{~s}, \mathrm{C}_{11}\right) ; 102.5(\mathrm{~d}$, $\left.J(P, C)=2 \mathrm{~Hz}, \mathrm{C}_{4}\right) ; 105.6\left(\mathrm{~m}, \mathrm{C}_{2}\right) ; 123.9\left(\mathrm{~s}, \mathrm{C}_{9}\right) ; 126.0(\mathrm{~d}, \mathrm{~J}(\mathrm{P}, \mathrm{C})=75 \mathrm{~Hz}$ $\left.\mathrm{C}_{\text {ipso }}\right) ; 128.0\left(\mathrm{~s}, \mathrm{C}_{7}\right) ; 128.7\left(\mathrm{~d}, J(\mathrm{P}, \mathrm{C})=15 \mathrm{~Hz}, \mathrm{C}_{5}\right) ; 128.8(\mathrm{~d}, J(\mathrm{P}, \mathrm{C})=12$ $\left.\mathrm{Hz}, \mathrm{C}_{\text {meta }}\right) ; 130.0$ (s, $\left.\mathrm{C}_{6}\right) ; 130.5$ (s, $\left.\mathrm{C}_{8}\right) ; 131.5$ (d, J(P,C) =12 Hz, Cortho); $132.1\left(\mathrm{~d}, J(\mathrm{P}, \mathrm{C})=3 \mathrm{~Hz}, \mathrm{C}_{\text {para }}\right) ; 133.6\left(\mathrm{~d}, J(\mathrm{P}, \mathrm{C})=1 \mathrm{~Hz}, \mathrm{C}_{10}\right) ; 135.1(\mathrm{~d}$, $\left.J(P, C)=75 \mathrm{~Hz}, C_{\alpha}\right) ; 136.0\left(d, J(P, C)=9 \mathrm{~Hz}, C_{1}\right) ; 141.5(d, J(P, C)=26 \mathrm{~Hz}$ $\left.\mathrm{C}_{\beta}\right) ; 160.9\left(\mathrm{~s}, \mathrm{C}_{3}\right) .{ }^{31} \mathrm{P}$ NMR $\left(160 \mathrm{MHz}, \mathrm{CDCl}_{3}\right): \delta+58.0$ (s). HRMS (ESI, $\left.\mathrm{CH}_{2} \mathrm{Cl}_{2} / \mathrm{MeOH}, 9 / 1, \mathrm{~m} / \mathrm{z}\right):[\mathrm{M}+\mathrm{H}]^{+}$calcd. for $\mathrm{C}_{58} \mathrm{H}_{72} \mathrm{O}_{4} \mathrm{PS}, 895.4889$; found 895.4886. Anal. Calcd. for $\mathrm{C}_{58} \mathrm{H}_{71} \mathrm{O}_{4} \mathrm{PS}$ : C, 77.82, H, 7.99; Found: C, 78.03, H, 8.33.

Synthesis of $3 a^{\circ}$. Compound $2 a^{\circ}$ (50 mg, $0.08 \mathrm{mmol}, 1$ eq.) was dissolved in $200 \mathrm{~mL}$ of toluene. The solution was sparged with argon for $15 \mathrm{~min}$ then $1 \mathrm{~mL}$ of propylene oxide (PPO) and $\mathrm{I}_{2}$ (43 mg, 2.1 eq.) were added. The solution was irradiated during $20 \mathrm{~h}$ with UV light using a Heraeus TQ 150 mercury vapor lamp. Then the solvent were evaporated and the crude was purified by chromatography on silica gel using dichloromethane:methanol $(99: 1, \mathrm{v} / \mathrm{v})$ as eluent to afford $3 \mathrm{a}^{\circ}$ as an orange solid (5 mg, $10 \%) .{ }^{1} \mathrm{H}$ NMR $\left.\left(400 \mathrm{MHz}, \mathrm{CDCl}_{3}\right)\right): \delta 3.70(\mathrm{~m}, 6 \mathrm{H}$, $\left.\mathrm{OCH}_{3}\right) ; 3.81\left(\mathrm{~s}, 3 \mathrm{H}, \mathrm{OCH}_{3}\right) ; 4.09\left(\mathrm{~s}, 3 \mathrm{H}, \mathrm{OCH}_{3}\right) ; 6.42-6.48\left(\mathrm{~m}, 1 \mathrm{H}, \mathrm{H}_{4}\right)$; $6.74\left(\mathrm{~d}, 1 \mathrm{H},{ }^{4} \mathrm{~J}(\mathrm{H}, \mathrm{H})=2 \mathrm{~Hz}, \mathrm{H}_{4}\right) ; 7.08\left(\mathrm{ddd}, 1 \mathrm{H},{ }^{4} \mathrm{~J}(\mathrm{H}, \mathrm{H})=2 \mathrm{~Hz},{ }^{3} \mathrm{~J}(\mathrm{H}, \mathrm{H})\right.$ $\left.=8 \mathrm{~Hz},{ }^{3} \mathrm{~J}(\mathrm{H}, \mathrm{H})=8 \mathrm{~Hz}, \mathrm{H}_{9}\right) ; 7.13\left(\mathrm{~d}, 1 \mathrm{H},{ }^{4} \mathrm{~J}(\mathrm{H}, \mathrm{H})=2 \mathrm{~Hz}, \mathrm{H}_{2}\right) ; 7.35$ (ddd, $\left.2 \mathrm{H},{ }^{2} J(\mathrm{H}, \mathrm{H})=8 \mathrm{~Hz},{ }^{2} \mathrm{~J}(\mathrm{H}, \mathrm{H})=8 \mathrm{~Hz}, J(\mathrm{P}, \mathrm{H})=3 \mathrm{~Hz}, \mathrm{H}_{\text {meta }}\right) ; 7.40-7.50(\mathrm{~m}$, $\left.2 \mathrm{H}, \mathrm{H}_{10}, \mathrm{H}_{\text {para }}\right) ; 7.69\left(\mathrm{dd}, 1 \mathrm{H},{ }^{3} \mathrm{~J}(\mathrm{H}, \mathrm{H})=8 \mathrm{~Hz},{ }^{3} \mathrm{~J}=8 \mathrm{~Hz}, \mathrm{H}_{10}\right) ; 7.75(\mathrm{~d}, 1 \mathrm{H}$, $\left.{ }^{3} \mathrm{~J}(\mathrm{H}, \mathrm{H})=8 \mathrm{~Hz}, \mathrm{H}_{8}\right) ; 7.80\left(\mathrm{ddd}, 2 \mathrm{H},{ }^{4} \mathrm{~J}(\mathrm{H}, \mathrm{H})=2 \mathrm{~Hz},{ }^{3} \mathrm{~J}(\mathrm{H}, \mathrm{H})=8 \mathrm{~Hz}\right.$, $\left.J(P, H)=14 \mathrm{~Hz}, \mathrm{H}_{\text {ortho }}\right) ; 8.16\left(\mathrm{~d}, 1 \mathrm{H},{ }^{3} \mathrm{~J}(\mathrm{H}, \mathrm{H})=8 \mathrm{~Hz}, \mathrm{H}_{11}\right) ; 8.22\left(\mathrm{~d}, 1 \mathrm{H},{ }^{3} \mathrm{~J}\right.$ $\left.(\mathrm{H}, \mathrm{H})=8 \mathrm{~Hz}, \mathrm{H}_{11}\right) ; 9.48\left(\mathrm{~d}, 1 \mathrm{H},{ }^{3} \mathrm{~J}(\mathrm{H}, \mathrm{H})=8 \mathrm{~Hz}, \mathrm{H}_{9}\right)$. Due to fluxional behavior of the molecule, $\mathrm{H}_{2}$ and $\mathrm{H}_{6}$ are not observed. ${ }^{13} \mathrm{C}$ NMR $(100$ $\left.\left.\mathrm{MHz}, \mathrm{CDCl}_{3}\right): \delta 55.4\left(\mathrm{~s}, \mathrm{OCH}_{3}\right)^{\prime}\right) ; 55.5\left(\mathrm{~s}, \mathrm{OCH}_{3}\right) ; 55.6\left(\mathrm{~s}, \mathrm{OCH}_{3}\right) ; 55.7(\mathrm{~s}$, $\left.\mathrm{OCH}_{3}\right) ; 100.5\left(\mathrm{~s}, \mathrm{C}_{2}\right) ; 101.3\left(\mathrm{~s}, \mathrm{C}_{4}\right) ; 102.3\left(\mathrm{~s}, \mathrm{C}_{4^{\prime}}\right) ; 106.3\left(\mathrm{~s}, \mathrm{C}_{6^{\prime}}\right.$ ou $\left.\mathrm{C}_{2^{\prime}}\right) ;$ $105.9\left(\mathrm{~s}, \mathrm{C}_{6}\right.$, ou $\left._{2^{\prime}}\right) ; 106.4\left(\mathrm{~d}, J(\mathrm{P}, \mathrm{C})=8 \mathrm{~Hz}, \mathrm{C}_{6}\right) ; 120.4\left(\mathrm{~s}, \mathrm{C}_{11}\right) ; 122.6$ $\left(\mathrm{s}, \mathrm{C}_{7}\right) ; 124.3\left(\mathrm{~s}, \mathrm{C}_{11^{\prime}}\right) ; 127.9\left(\mathrm{~s}, \mathrm{C}_{9}\right) ; 128.6\left(\mathrm{~s}, \mathrm{C}_{9}\right) ; 128.8(\mathrm{~d}, J(\mathrm{P}, \mathrm{C})=16$ $\left.\mathrm{Hz}, \mathrm{C}_{7}\right) ; 129.3$ (d, J(P,C) $\left.=13 \mathrm{~Hz}, \mathrm{C}_{\text {meta }}\right) ; 129.4$ (large s, $\left.\mathrm{C}_{8}, \mathrm{C}_{10}\right) ; 130.0$ $\left(\mathrm{s}, \mathrm{C}_{12}\right) ; 130.4\left(\mathrm{~s}, \mathrm{C}_{10^{\circ}}\right) ; 130.8\left(\mathrm{~s}, \mathrm{C}_{8}\right) ; 131.2\left(\mathrm{~d}, J(\mathrm{P}, \mathrm{C})=11 \mathrm{~Hz}, \mathrm{C}_{\text {ortho }}\right)$; 132.2 (s, $\left.\mathrm{C}_{\text {para }}\right) ; 132.3\left(\mathrm{~s}, \mathrm{C}_{1}\right) ; 134.5\left(\mathrm{~s}, \mathrm{C}_{12}\right) ; 134.5\left(\mathrm{~s}, \mathrm{C}_{1^{1}}\right) ; 159.3\left(\mathrm{~s}, \mathrm{C}_{3}\right)$; $161.0\left(\mathrm{~s}, \mathrm{C}_{5}\right) ; 161.3\left(\mathrm{C}_{3^{\prime}}\right.$ or $\left.\mathrm{C}_{5^{\prime}}\right) ; 161.4\left(\mathrm{~s}, \mathrm{C}_{3^{\prime}}\right.$ or $\left.\mathrm{C}_{5^{\prime}}\right) . \mathrm{C}_{\alpha}, \mathrm{C}_{\beta}$ and $\mathrm{C}_{\mathrm{ipso}}$ are not observed. ${ }^{31} \mathrm{P}$ NMR $\left(160 \mathrm{MHz}, \mathrm{CDCl}_{3}\right): \delta+39.6$ (s). HRMS (ESI, $\left.\mathrm{CH}_{2} \mathrm{Cl}_{2} / \mathrm{MeOH}, 95 / 5, \mathrm{~m} / \mathrm{z}\right):[\mathrm{M}+\mathrm{Na}]^{+}$calcd. for $\mathrm{C}_{38} \mathrm{H}_{29} \mathrm{O}_{5} \mathrm{PNa}$ : 619.16503; found 619.1645. Anal. Calcd. for $\mathrm{C}_{38} \mathrm{H}_{29} \mathrm{O}_{5} \mathrm{P}: \mathrm{C}, 76.50, \mathrm{H}, 4.90$; Found: $\mathrm{C}$, $76.70, \mathrm{H}, 5.22$.

Synthesis of $4 b^{s}$. Compound $2 b^{s}$ (100 mg, $0.16 \mathrm{mmol}, 1$ eq.) was dissolved in $500 \mathrm{~mL}$ of toluene. The solution was sparged with argon for $15 \mathrm{~min}$ then $1 \mathrm{~mL}$ of PPO and $\mathrm{I}_{2}$ (86 mg, 2.1 eq.) were added. The solution was irradiated during $20 \mathrm{~h}$ with UV light using a Heraeus TQ 150 mercury vapor lamp. Then the solvent were evaporated and the crude was purified by chromatography on basic alumina (90 $\AA$ ) using a $3 \%$ solution of ethyl acetate in heptane as eluent to afford $\mathbf{4} \mathbf{b}^{\mathbf{S}}$ as an orange solid (30 mg, $30 \%)$. ${ }^{1} \mathrm{H}$ NMR $\left(300 \mathrm{MHz}, \mathrm{CDCl}_{3}\right): \delta 0.95\left(\mathrm{t},{ }^{3} \mathrm{~J}(\mathrm{H}, \mathrm{H})=6 \mathrm{~Hz}\right.$, $12 \mathrm{H}, \mathrm{H}_{16}$ and $\left.\mathrm{H}_{16^{\prime}}\right) ; 1.10-1.50\left(\mathrm{~m}, 16 \mathrm{H}, \mathrm{H}_{14}, \mathrm{H}_{14^{\prime}}, \mathrm{H}_{15}\right.$ and $\left.\mathrm{H}_{15^{\prime}}\right) ; 1.45-1.55$ $\left(\mathrm{m}, 4 \mathrm{H}, \mathrm{H}_{13}\right) ; 1.55-1.65\left(\mathrm{~m}, 4 \mathrm{H}, \mathrm{H}_{13}\right) ; 1.75-1.85\left(\mathrm{~m}, 4 \mathrm{H}, \mathrm{H}_{12}\right) ; 1.95-2.10$ $\left(\mathrm{m}, 4 \mathrm{H}, \mathrm{H}_{12}\right) ; 3.89-4.21\left(\mathrm{~m}, 8 \mathrm{H}, \mathrm{H}_{11}\right.$ and $\left.\mathrm{H}_{11}\right) ; 6.65\left(\mathrm{~d}, 2 \mathrm{H},{ }^{4} \mathrm{~J}(\mathrm{H}, \mathrm{H})=2 \mathrm{~Hz}\right.$, $\left.\mathrm{H}_{4}\right) ; 7.28-7.34\left(\mathrm{~m}, 2 \mathrm{H}, \mathrm{H}_{\text {meta }}\right) ; 7.36\left(\mathrm{~d}, 2 \mathrm{H},{ }^{4} \mathrm{~J}(\mathrm{H}, \mathrm{H})=2 \mathrm{~Hz}, \mathrm{H}_{2}\right) ; 7.43(\mathrm{~m}$, $\left.1 \mathrm{H}, \mathrm{H}_{\text {para }}\right) ; 7.61\left(\mathrm{dd}, 2 \mathrm{H},{ }^{3} \mathrm{~J}(\mathrm{H}, \mathrm{H})=8 \mathrm{~Hz},{ }^{3} \mathrm{~J}(\mathrm{H}, \mathrm{H})=8 \mathrm{~Hz}, \mathrm{H}_{8}\right) ; 8.02(\mathrm{dd}, 2 \mathrm{H}$, $\left.{ }^{3} \mathrm{~J}(\mathrm{H}, \mathrm{H})=8 \mathrm{~Hz}, J(\mathrm{P}, \mathrm{H})=14 \mathrm{~Hz}, \mathrm{H}_{\text {ortho }}\right) ; 8.12\left(\mathrm{~d}, 2 \mathrm{H},{ }^{3} \mathrm{~J}(\mathrm{H}, \mathrm{H})=8 \mathrm{~Hz}, \mathrm{H}_{9}\right)$; $9.38\left(\mathrm{~d}, 2 \mathrm{H},{ }^{3} \mathrm{~J}(\mathrm{H}, \mathrm{H})=8 \mathrm{~Hz}, \mathrm{H}_{7}\right) .{ }^{13} \mathrm{C}$ NMR $\left(100 \mathrm{MHz}, \mathrm{CDCl}_{3}\right): \delta 14.2(\mathrm{~s}$, $\left.\mathrm{C}_{16}\right) ; 14.3\left(\mathrm{~s}, \mathrm{C}_{16}\right) ; 22.7\left(\mathrm{~s}, \mathrm{C}_{15}\right) ; 22.8\left(\mathrm{~s}, \mathrm{C}_{15}\right) ; 26.0\left(\mathrm{~s}, \mathrm{C}_{14}\right) ; 26.2\left(\mathrm{~s} \mathrm{C}_{14}\right)$; $29.2\left(\mathrm{~s}, \mathrm{C}_{13}\right) ; 29.3\left(\mathrm{~s}, \mathrm{C}_{13}\right) ; 31.7\left(\mathrm{~s}, \mathrm{C}_{12}\right) ; 31.8\left(\mathrm{~s}, \mathrm{C}_{12}\right) ; 68.2\left(\mathrm{~s}, \mathrm{C}_{11}\right) ; 69.3$ $\left(\mathrm{s}, \mathrm{C}_{11}\right) ; 99.1$ (d, $\left.J(\mathrm{P}, \mathrm{C})=5 \mathrm{~Hz}, \mathrm{C}_{2}\right) ; 101.1$ (s, $\left.\mathrm{C}_{4}\right) ; 116.3(\mathrm{~d}, J(\mathrm{P}, \mathrm{C})=6$ $\left.\mathrm{Hz}, \mathrm{C}_{2}\right) ; 120.7\left(\mathrm{~s}, \mathrm{C}_{9}\right) ; 123.5\left(\mathrm{~d}, J(\mathrm{P}, \mathrm{C})=11 \mathrm{~Hz}, \mathrm{C}_{5}\right) ; 127.0(\mathrm{~d}, J(\mathrm{P}, \mathrm{C})=$ $\left.95 \mathrm{~Hz}, \mathrm{C}_{\alpha}\right) ; 128.2\left(\mathrm{~s}, \mathrm{C}_{7}\right) ; 129.0\left(\mathrm{~d}, J(\mathrm{P}, \mathrm{C})=13 \mathrm{~Hz}, \mathrm{C}_{\text {meta }}\right) ; 129.1$ (d, $\left.J(P, C)=77 \mathrm{~Hz}, \mathrm{C}_{\text {ipso }}\right) ; 129.6\left(\mathrm{~s}, \mathrm{C}_{8}\right) ; 130.9\left(\mathrm{~d}, J(\mathrm{P}, \mathrm{C})=12 \mathrm{~Hz}, \mathrm{C}_{\text {ortho }}\right)$; $132.2\left(\mathrm{~d}, J(\mathrm{P}, \mathrm{C})=3 \mathrm{~Hz}, \mathrm{C}_{\text {para }}\right) ; 132.9\left(\mathrm{~d}, J(\mathrm{P}, \mathrm{C})=11 \mathrm{~Hz}, \mathrm{C}_{1}\right) ; 133.8(\mathrm{~s}$, $\left.\mathrm{C}_{6}\right) ; 138.3\left(\mathrm{~d}, J(\mathrm{P}, \mathrm{C})=20 \mathrm{~Hz}, \mathrm{C}_{\beta}\right) ; 158.7\left(\mathrm{~s}, \mathrm{C}_{3}\right) ; 160.3(\mathrm{~d}, J(\mathrm{P}, \mathrm{C})=2 \mathrm{~Hz}$, $\left.\mathrm{C}_{3}\right), \mathrm{C}_{10}$ is not observed. ${ }^{31} \mathrm{P} \mathrm{NMR}\left(160 \mathrm{MHz}, \mathrm{CDCl}_{3}\right): \delta+45.6$ (s). HR MS (ESI, $\mathrm{CH}_{2} \mathrm{Cl}_{2} / \mathrm{MeOH}, 95 / 5, \mathrm{~m} / \mathrm{z}$ ): $[\mathrm{M}+\mathrm{H}]^{+}$calcd for $\mathrm{C}_{58} \mathrm{H}_{68} \mathrm{O}_{4} \mathrm{PS}$ : 891.4576, Found 891.4568. Anal. Calcd. for $\mathrm{C}_{58} \mathrm{H}_{67} \mathrm{O}_{4} \mathrm{PS}: \mathrm{C}, 78.17, \mathrm{H}, 7.58$; Found: C, $78.29, \mathrm{H}, 7.80$.

\section{Acknowledgements}

Acknowledgements This work is supported by the Ministère de la Recherche et de l'Enseignement Supérieur, the CNRS, the Région Bretagne, China-French associated international laboratory in "Functional Organophosphorus Materials", Balaton PHC (830386K) - FR_12_TET_A044DF3B, the French National Research Agency (ANR)/Research Grants Council (RGC) Joint Research Scheme (ANR MOLMAT) and COST CM10302 (SIPS). The authors are grateful to C. Lescop for X-ray diffraction studies.

Keywords: Polyaromatic compounds • Phosphole •Aggregation OLEDs 
[1] (a) W. Jiang, Y. Li, Z. Wang Chem. Soc. Rev. 2013. (b) M. Hissler, P. W. Dyer, R. Réau Coord. Chem. Rev. 2003, 244, 1.

[2] (a) C. Fave, M. Hissler, K. Sénéchal, I Ledoux, J. Zyss, R. Réau, Chem. Commun. 2002, 1674.(b) B. Nohra, S. Graule, C. Lescop, R. Réau, R. J. Am Chem. Soc. 2006, 128, 3520. (c) S. Graule, M. Rudolph, N. Vanthuyne, J. Autschbach, C. Roussel, J. Crassous, R. Réau J. Am. Chem. Soc. 2009, 131 3183. (d) Y. Matano, A. Saito, T. Fukushima, Y. Tokudome, F. Suzuki, D. Sakamaki, H. Kaji, A. Ito, K. Tanaka, H. Imahori Angew. Chem. Int. Ed. 2011, 50, 8016. (e) A. Bruch, A. Fukazawa, E. Yamaguchi, S. Yamaguchi, A. Studer Angew. Chem. Int. Ed. 2011, 50, 12094. (f) Y. Ren, W. H. Kan, M. A Henderson, P. G. Bomben, C. P. Berlinguette, V. Thangadurai, V.; T. Baumgartner, T. J. Am. Chem. Soc. 2011, 133, 17014. (g) H. Chen, W. Delaunay, L. Yu, D. Joly, Z. Wang, J. Li, Z. Wang, C. Lescop, D. Tondelier, B. Geffroy, Z. Duan, M. Hissler, F. Mathey, R. Réau Angew. Chem. Int. Ed. 2012, 51, 214. (h) X. Wei, Z. Lu, X. Zhao, Z. Duan, F. Mathey, Angew. Chem. Int. Ed. 2014, 53, 1 .

[3] (a) H. Chen, W. Delaunay, J. Li, Z. Wang, P.-A. Bouit, D. Tondelier, B. Geffroy, F. Mathey, Z. Duan, R. Réau, M. Hissler, M. Org. Lett. 2013, 15 330.(b) O. Fadhel, M. Gras, N. Lemaitre, V. Deborde, M. Hissler, B. Geffroy, R. Réau. Adv. Mater. 2009, 21, 1261.(c) C. Fave,T. -Y. Cho, M. Hissler, C. W. Chen, T. -Y. Luh, C. -C. Wu, R. Réau J. Am. Chem. Soc. 2003, 125, 9254.

[4] (a) K. S. Novoselov; A. K. Geim; S. V. Morozov; D. Jiang; M. I. Katsnelson; I. V. Grigorieva; Dubonos, S. V.; Firsov, A. A. Nature 2005, 438, 197. (b) K. S. Novoselov, A. K. Geim, S. V. Morozov, D. Jiang, Y. Zhang, S. V. Dubonos, I. V. Grigorieva, A. A. Firsov. Science 2004, 306. (c) L. Chen, Y. Hernandez, X. Feng, K. Müllen Angew. Chem. Int. Ed. 2012, 51, 7640. (d) M. D. Watson, A. Fechtenkotter, K. Müllen Chem. Rev. 2001, 101, 1267. (e) J Wu, W. Pisula, K. Müllen. Chem. Rev. 2007, 107, 718. (f) Y. Zhong, B. Kumar S. Oh, M. Trinh, Y. Wu, K. Elbert, P. Li, X. Zhu, S. Xiao, F. Ng, M. L. Steigerwald, C. Nuckolls. J. Am. Chem. Soc. 2014, 136, 15215.

[5] (a) L. Schmidt-Mende, A. Fechtenkotter, K. Mullen, E.; Moons, R. H. Friend, J. D. MacKenzie Science 2001, 293, 1119. (b) A. A. Gorodetsky, C. -Y Chiu, T. Schiros, M. Palma, M. Cox, Z. Jia, W. Sattler, I. Kymissis. M. Steigerwald, C. Nuckolls. Angew. Chem. Int. Ed. 2010, 49, 7909.

[6] W. Pisula, A. Menon, M. Stepputat, I. Lieberwirth, U. Kolb, A. Tracz, H. Sirringhaus, T. Pakula, K. Mullen, M. Adv. Mater. 2005, 17, 684

[7] (a) S. M. Draper, D. J. Gregg, R; Madathil. J. Am. Chem. Soc. 2002, 124 3486.(b) M. Takase, T. Narita, W. Fujita, M. S. Asano, T. Nishinaga, H Benten, K. Yoza, K. Müllen. J. Am. Chem. Soc. 2013, 135, 8031.(c) S. M. Draper, D. J. Gregg, E. R. Schofield, W. R. Browne, M. Duati, J. G. Vos, P. Passaniti. J. Am. Chem. Soc. 2004, 126, 8694.

[8] (a) C. J. Martin, B. Gil, S. D. Perera, S. M. Draper Chem. Commun 2011, 47, 3616. (b) L. Chen, S. R. Puniredd, Y.-Z. Tan, M. Baumgarten, U. Zschieschang, V. Enkelmann, W. Pisula, X. Feng, H. Klauk, K. Müllen. J. Am Chem. Soc. 2012, 134, 17869. (c) R. Benshafrut, M. Rabinovitz, R. E. Hoffman, N. Ben-Mergui, K. Müllen, V. S. lyer Eur. J. Org. Chem. 1999, 1999, 37.

[9] D. Wu, W. Pisula, M. C. Haberecht, X. Feng, K. Müllen. Org. Lett. 2009 11,5686 .

[10] (a) T. Hatakeyama, S. Hashimoto, S. Seki, M. Nakamura J. Am. Chem Soc. 2011, 133, 18614. (b) Z. Zhou, A. Wakamiya, T. Kushida, S. Yamaguch J. Am. Chem. Soc. 2012, 134, 4529. (c) S. Saito, K. Matsuo, S. Yamaguchi. J. Am. Chem. Soc. 2012, 134, 9130. (d) C. Dou, S. Saito, K. Matsuo, I. Hisaki, S. Yamaguchi. Angew. Chem. Int. Ed. 2012, 51, 12206.

[11] (a) A. C. Grimsdale, K. L. Chan, R. E. Martin P. G. Jokisz, A. B Holmes Chem Rev 2009, 109, 897. (b) E. E. Havinga, W. Hoeve, H. Wynberg. Synth Met. 1993, 55, 299. (c) K. Colladet, S. Fourier; T. J. Cleji, L. Laurence, J. Gelan, D. Vanderzande, D. Macromolecules 2007, 40, 65.

[12] Y. Matano, T. Miyajima, T. Fukushima, H. Kaji,Y. Kimura, H. Imahori, H. Chem. Eur. J. 2008, 14, 8102

[13] O. Fadhel, D. Szieberth, V. Deborde, C. Lescop, L. Nyulaszi, M. Hissler, R. Réau Chem. Eur. J. 2009, 15, 4914.

[14] P. -A. Bouit, A. Escande, R. Szücs, D. Szieberth, C. Lescop, L. Nyulászi M. Hissler, R. Réau J. Am. Chem. Soc. 2012, 134, 6524.

[15] Y. Ruiz-Morales, J. Phys. Chem. A. 2002, 106, 11283

[16] (a) P. J. Fagan, W. A. Nugent, J. C. Calabrese, J. Am. Chem. Soc. 116 (1994) 1880. (b) F. Mathey, Chem. Rev. 88 (1988) 429. (c) L. D. Quin, Comprehensive Heterocyclic Chemistry (Ed.: A. R. Katritzky), Pergamon, Oxford, 1996, 757. (d) X. Sava, N. Mézaille, N. Maigrot, F. Nief, L. Ricard, F. Mathey, P. Le Floch, Organometallics 18 (1999) 4205.

[17] L. Liu, B. Yang, T. J. Katz, M. K. Poindexter J. Org. Chem. 1991, 56 3769

[18] Note that polyaromatic oxophosphole $4 a^{\circ}$ could then be obtained in higher yield from $4 \mathrm{a}^{\mathrm{S}}$ using our previously reported protection-deptotection strategy, see reference 14 .

[19] It is worth noting that $\mathbf{3 a S}$ is a chiral molecule that cristallizes as a racemic mixture.

[20] I.B. Berlman, Handbook of Fluorescence Spectra of Aromatic Molecules, 2nd ed., Academic Press, New York, 1971

[21] (a) E. D. Donato, M. Tommasini, G. Fustella, L. Brambilla, C. Castiglioni, G. Zerpi, C. D. Simpson, K. Mullen, F. Negri Chem. Phys. 2004 301, 81. (b) C. Castiglioni, E. Di Donato, M. Tommasini, F. Negri, G. Zerbi Synthetic Metals 2003, 139, 885 (c) M. Rigolio, C. Castiglioni, G. Zerbi, F. Negri J. Mol. Struct. 2001, 563-564, 79.
(22] (a) P. von Raqué Schleyer, H. Jiao, N. J. R. van Eikema Hommes, V. G. Malkin, O. L. Malkina J. Am. Chem. Soc. 1997, 119, 12669. (b) P. von Raque Schleyer, C. Maerker, A. Dransfeld, H. Jiao, N. J. R. van Eikema Hommes J. Am. Chem. Soc. 1996, 118, 6317. (c) P. von Raqué Schleyer, M. Manoharan, Z. X. Wang, B. Kiran, H. Jiao, R. Puchta, N. J. R. van Eikema Hommes Organic Letters 2001, 3, 2465.

[23] (a) L. Nyulaszi, O. Holloczki, C. Lescop, M. Hissler, R. Réau. Org. Biomol. Chem. 2006, 4, 996. (b) Z. Mucsi, G. Keglevich Eur. J. Org. Chem. 2007, 2007, 4765. (c) Z. Benkö, L. Nyulászi Aromatic Phosphorus Heterocycles. In Aromaticity in Heterocyclic Componds. Krygowski, T. M.; Cyransky, M. K (Editors). Vol 19 in Topics in Heterocyclic Chemistry (Gupta R. R. (Series Editor) Springer, Heidelberg, 2009. pp. 27-83.

[24] O. Holloczki, L. Nyulaszi Struct. Chem. 2011, 22, 1385

[25] (a) G. Portella, J. Poater, M. Solà, J. Phys. Org. Chem. 2005, 18, 785. (b) M. S. Deleuze. Chem. Phys. 2006, 239, 22. (c) E. Clar The Aromatic Sextet; Wiley: New York, 1972; Clar, E. Polycyclic Hydrocarbons; Academic Press: London, 1964.(d) D. Ghosh, G. Periyasamy, S. K. Pati Phys. Chem. Chem. Phys. 2011, 13, 20627. (e) J. -I. Aihara Chem. Phys. Lett. 2002, 365, 34. [26] B. Hajgató, M. S. Deleuze, K. Ohno Chem. Eur. J 2006, 12, 5757.

[27] (a) C. W. Bird Tetrahedron 1985, 41, 1409. (b) C. W. Bird Tetrahedron 1986, 42, 89. (c) C. W. Bird Tetrahedron 1987, 43, 4725-4730. (d) C. W. Bird Tetrahedron 1992, 48, 335-3

[28] L. Nyulászi, P. Várnai, T. Veszprémi Journal of Molecular Structure: THEOCHEM 1995, 358, 55-61.

[29] (a) Y. Li, A. H. Flood Angew. Chem. Int. Ed. 2008, 47, 2649.(b) R. B. Martin Chem Rev 1996, 96, 3043.(c) Z L. Chen, C. R Saha-Möller, F. Würthner Chem. Soc. Rev. 2009, 38, 564.(d) T. F. A. De Greef, M. M. J. Smulders, M. Wolffs, A. P. H. J. Schenning, R. P. Sijbesma, E. W. Meijer Chem. Rev. 2009, 109, 5687.

[30] A very recent model to determine the influence on the thermodynamics of chloroform in supramolecular polymerizations has been recently developped (a) P. A. Korevaar, C. Schaefer, T. F. A. de Greef, E. Meijer. Am. Chem. Soc 2012, 134, 13482. (b) F. García, P. A. Korevaar, A. Verlee, E. W. Meijer, A. R A. Palmans, L. Sánchez Chem. Commun. 2013, 49, 8674.

[31] M. Kastler, W. Pisula, D. Wasserfallen, T. Pakula, K. Müllen J. Am. Chem. Soc. 2005, 127, 4286 .

[32] This phenomenon is not in contrast with the NMR titrations, as AIE is due intramolecular motion restrictions in non-organized aggregates, see reference

[33] Y. Hong, J. W. Y. Lam, B. Z. Tang Chem. Soc. Rev. 2011, 40, 5361

[34] Note that these compounds show sufficient thermal stability to be inserted into devices (table 2)

[35] J. G. Jang, ; H. J. Ji, H. S. Kim, J. C. Jeong Current Appl. Phys. 2011, 11, S251.

[36] Z. Otwinowski, W. Minor In Methods in Enzymology, (Ed.: C.W. Carter, Jr. \& R.M. Sweet[, New York:Academic Press, 1997, 276, 307.

[37] A.Altomare, M. C. Burla, M. Camalli, G. Cascarano, C. Giacovazzo, A. Guagliardi, A. G. G. Moliterni, G. Polidori, R. Spagna J. of Applied Cryst. 1999, 32,115 .

[38] Sheldrick G.M., SHELX97, Program for the Refinement of Crystal Structures, University of Göttingen, Germany, 1997.

[39] International Tables for X-ray Crystallography, vol C, Ed. Kluwer, Dordrech, 1992

[40] Gaussian 09, Revision B.01, M. J. Frisch, G. W. Trucks, H. B. Schlegel, G. E. Scuseria, M. A. Robb, J. R. Cheeseman, G. Scalmani, V. Barone, B. Mennucci, G. A. Petersson, H. Nakatsuji, M. Caricato, X. Li, H. P. Hratchian, A. F. Izmaylov, J. Bloino, G. Zheng, J. L Sonnenberg, M. Hada, M. Ehara, K. Toyota, R. Fukuda, J. Hasegawa, M. Ishida, T. Nakajima, Y. Honda, O. Kitao, H. Nakai, T. Vreven, J. A. Montgomery, Jr., J. E. Peralta, F. Ogliaro, M. Bearpark, J. J. Heyd, E. Brothers, K. N. Kudin, V. N. Staroverov, T. Keith, R. Kobayashi, J. Normand, K. Raghavachari, A. Rendell, J. C. Burant, S. S. lyengar, J. Tomasi, M. Cossi, N. Rega, J. M. Millam, M. Klene, J. E. Knox, J. B. Cross, V. Bakken, C. Adamo, J. Jaramillo, R. Gomperts, R. E. Stratmann, O. Yazyev, A. J. Austin, R. Cammi, C. Pomelli, J. W. Ochterski, R. L. Martin, K. Morokuma, V. G. Zakrzewski, G. A. Voth, P. Salvador, J. J. Dannenberg, S. Dapprich, A. D. Daniels, O. Farkas, J. B. Foresman, J. V. Ortiz, J. Cioslowski, D. J. Fox, Gaussian, Inc., Wallingford CT, 2010

[41] (a) A. D. Becke J. Chem. Phys. 1993, 98, 5648. (b) C. Lee, W. Yang, R. G. Parr. Phys. Rev. B 1988, 37, 785

[42] G. Schaftenaar, J. H. Noordik J. Comput.-Aided Mol. Design 2000, 14 123.

[43] W. Humphrey, A. Dalke, K. Schulten, J. Molec. Graphics 1996, 14, 33. 